\title{
Review
}

Pathophysiology

Diabetes Metab J 2021;45:285-311

https://doi.org/10.4093/dmj.2020.0250

pISSN 2233-6079 · eISSN 2233-6087

DIABET\&S \& METABOLISM JOURNAL

\section{Hyperinsulinemia in Obesity, Inflammation, and Cancer}

\author{
Anni M.Y. Zhang' ${ }^{1}$, Elizabeth A. Wellberg ${ }^{2}$, Janel L. Kopp ${ }^{1}$, James D. Johnson ${ }^{1}$ \\ ${ }^{1}$ Department of Cellular and Physiological Sciences, Life Sciences Institute, University of British Columbia, Vancouver, BC, Canada, \\ ${ }^{2}$ Department of Pathology, University of Oklahoma Health Sciences Center, Stephenson Cancer Center, Harold Hamm Diabetes Center, Oklahoma City, OK, USA
}

\begin{abstract}
The relative insufficiency of insulin secretion and/or insulin action causes diabetes. However, obesity and type 2 diabetes mellitus can be associated with an absolute increase in circulating insulin, a state known as hyperinsulinemia. Studies are beginning to elucidate the cause-effect relationships between hyperinsulinemia and numerous consequences of metabolic dysfunctions. Here, we review recent evidence demonstrating that hyperinsulinemia may play a role in inflammation, aging and development of cancers. In this review, we will focus on the consequences and mechanisms of excess insulin production and action, placing recent findings that have challenged dogma in the context of the existing body of literature. Where relevant, we elaborate on the role of specific signal transduction components in the actions of insulin and consequences of chronic hyperinsulinemia. By discussing the involvement of hyperinsulinemia in various metabolic and other chronic diseases, we may identify more effective therapeutics or lifestyle interventions for preventing or treating obesity, diabetes and cancer. We also seek to identify pertinent questions that are ripe for future investigation.
\end{abstract}

Keywords: Breast neoplasms; Diabetes mellitus, type 2; Insulin; Longevity; Metabolic syndrome; Pancreatic neoplasms

\section{INTRODUCTION}

Insulin is a peptide hormone secreted by pancreatic $\beta$-cells to regulate glucose homeostasis. Since its discovery in Canada in 1921 [1], insulin has saved millions of lives. However, in recent years, many studies have demonstrated that excess insulin (also known as hyperinsulinemia) might play a complex role in multiple diseases. In this review, we will focus on the cause-effect relationships between hyperinsulinemia, aging, obesity, inflammation, and cancers. As several complementary reviews have extensively discussed the importance of hyperinsulinemia in obesity [2-4] and cancer [5] separately, we will focus on expanding and integrating these concepts together. We will also discuss the potential molecular mechanisms mediating the effects of hyperinsulinemia on these disorders. We will discuss the limitations of the current evidence base and areas for future study. We hope that by targeting hyperinsulinemia, we may develop new therapeutic strategies for the prevention and/or treatment of obesity, diabetes, and cancers.

\section{INSULIN AND INSULIN SIGNALING MECHANISMS IN THE CONTROL OF METABOLISM AND LIFESPAN}

In order to better understand the (patho)physiological effects of insulin, we must first consider its evolution. Insulin and its related peptides are ancient, evolutionarily conserved, anabolic neurohormones [6-9]. Humans have one INS gene, two insulin-like growth factor genes (IGF1, IGF2), several insulin-like peptides, and relaxins [10-13]. Mice have two insulin genes. Mice lacking either Ins1 or Ins2 have normal glucose, suggesting a genetic compensation $[14,15]$, but loss of both insulin genes is lethal $[15,16]$. Ins1 originated from a reverse-transcribed and partially processed Ins 2 mRNA transposition [17]
Corresponding author: James D. Johnson (D) https://orcid.org/0000-0002-7523-9433 Department of Cellular and Physiological Sciences, Life Sciences Institute, University of British Columbia, 2329 W Mall Vancouver, BC V6T 1Z4, Vancouver, BC, Canada

E-mail: James.d.johnson@ubc.ca
This is an Open Access article distributed under the terms of the Creative Commons Attribution Non-Commercial License (https://creativecommons.org/licenses/by-nc/4.0/) which permits unrestricted non-commercial use, distribution, and reproduction in any medium, provided the original work is properly cited. 
and is restricted to $\beta$-cells where it contributes $1 / 3$ rd of insulin synthesized and secreted into circulation [18]. Ins 2 is the ancestral gene that produces $2 / 3$ of the insulin mRNA in islets $[19,20]$, as well as trace amounts in the thymus [21] and brain [20]. Using mice as a genetically tractable model for mammalian insulin physiology has provided insight into obesity, diabetes, cancer, and other aging-associated diseases where changes in insulin levels and signaling are implicated.

Insulin and IGF have many similarities but also have key differences in their function and downstream signaling mechanisms. Insulin is recognized for its acute metabolic roles, whereas the IGFs are more commonly studied in association with growth, aging, and cancer [22]. Emerging evidence points to important 'growth factor' roles of insulin [20,23-32], as well as 'metabolic' roles of IGF1/IGF2 [33,34]. A conserved signaling pathway is largely shared between insulin and IGFs; thus, it is difficult to clearly separate the effects of insulin and IGF1/ IGF2. Unfortunately, the majority of studies in the literature, especially those reporting in vitro cell culture experiments, have used insulin concentrations that are many times higher than those found physiologically, confounding interpretation of these studies and clouding the field. Insulin binds to its receptor tyrosine kinase, insulin receptor (INSR) with an IC50 of $0.89 \mathrm{nM}$ and to the growth factor 1 receptor (IGF1R) with an IC50 of 30 to $400 \mathrm{nM}$ [35-37]. INSR/IGF1R can form heterodimer hybrid receptors that have a higher affinity for IGF1 than insulin [38-40]. Binding to the INSR and related receptors leads to tyrosine kinase autophosphorylation and binding of adapter proteins, called insulin receptor substrates (IRS1, IRS2, IRS3, IRS4), which attract the lipid kinase, phosphoinositide 3-kinase (PI3K). Phosphorylation of $\mathrm{PI}(4,5) \mathrm{P}_{2}$ to $\mathrm{PI}(3,4,5) \mathrm{P}_{3}$ by PI3K activates the PH-domain-containing kinase 3-phosphoinositide dependent protein kinase 1 (PDPK1), which in turn phosphorylates serine/threonine kinase AKT serine/threonine kinase 1 (AKT) [41]. Insulin-mediated activation of AKT leads to the phosphorylation of multiple signaling intermediates including the forkhead family box O (FOXO) family of transcription factors, glycogen synthase kinase 3 (GSK3), and the mammalian target of rapamycin complex 1 (mTORC1) complex $[41,42]$. Insulin signaling can also activate the Rasfamily GTPase (Ras)-mitogen-activated protein kinase (MAPK)/extracellular signal-regulated kinase (ERK) phosphorylation cascade via the adapter proteins SHC-transforming protein 1 (SHC1), growth factor receptor-bound protein 2 (GRB2), and son of sevenless (SOS) [41]. There are multiple levels of cross talk between the major 'arms' of insulin signaling, as well as cross talk to other signaling networks [38-40,43]. When investigated individually, virtually all aspects of the extended insulin signaling network have been linked to diabetes when strongly suppressed, to longevity when mildly suppressed, and to cancer when overactive [31,38,44-47].

We have learned much about the role of insulin and insulin signaling in longevity by studying relatively simple model organisms. INSR or IRS mutant flies live 50\% longer than wildtype flies $[48,49]$. Mice lacking IRS1 have increased lifespan compared to wildtype controls [50,51]. Studies in humans have linked insulin and IGF1 to longevity [9], with lower levels of these factors associated with longer life [52,53]. Mice with heterozygous loss of Igf1 $r$ were reported to have increased longevity [54], but this has been questioned [55]. Reducing circulating IGF1 by liver-specific gene ablation in female mice increases mean lifespan, but not maximum lifespan [56]. These observations and others demonstrate that IGF1 plays important roles in longevity [57], but also suggest that factors other than IGF1, such as insulin, may be important in some contexts. Mice lacking adipose tissue Insr are leaner and live longer than controls [58-60], but Insr loss also impacts IGF signaling via hybrid receptors $[24,26,61]$. Because the insulin and IGF ligands can (promiscuously) target receptor hetero dimers and each other's homodimers, the receptor ligands must be manipulated directly to understand insulin's role in metabolism and lifespan. Indeed, we found genetically reduced insulin production extended lifespan in mice [44]. In liver, gene networks related to cellular metabolism, circadian rhythm, proteostasis, and cell-cycle progression were altered in mice with reduced insulin [44]. Thus, insulin/insulin signaling is a positive regulator of energy storage and is a negative regulator of longevity in all animals studied to date (Fig. 1) [9,54,57,62,63]. Manipulations that reduce plasma glucose levels, and thereby circulating insulin, also extend lifespan [64], but it remains unclear whether the glucose effects are independent of insulin. Emerging evidence links hyperinsulinemia and/or hyperglycemia to mortality after infections, including severe acute respiratory syndrome coronavirus $2[65,66]$, but these concepts also require further mechanistic studies to determine causality.

\section{HYPERINSULINEMIA PLAYS A CAUSAL ROLE IN OBESITY}

The range of circulating insulin is relatively broad in healthy 


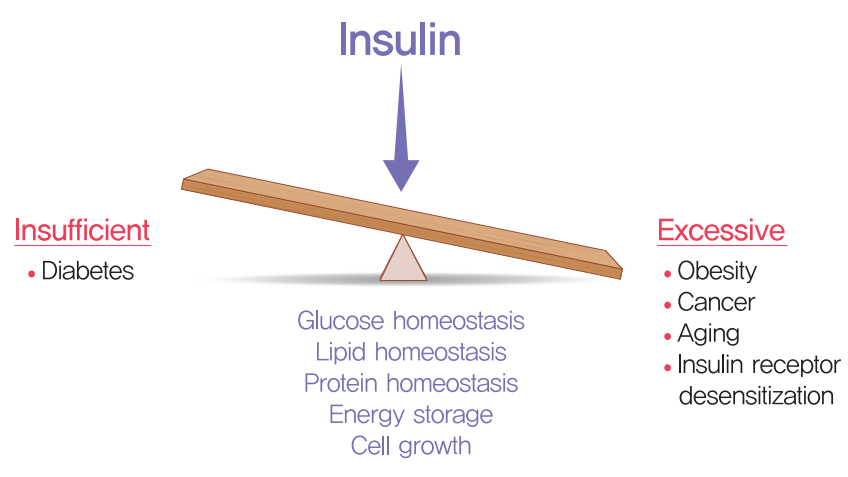

Fig. 1. Trade-offs with insufficient and excessive circulating insulin levels.

individuals and peaks approximately 30 minutes after glucose administration, remaining elevated above baseline for over 2 hours. Studies that tracked insulin over 24 hours found that fasting insulin averaged $60 \mathrm{pmol} / \mathrm{L}$ while post-meal insulin peaked at $420 \mathrm{pmol} / \mathrm{L}$ [67]. In individuals with obesity, fasting insulin was $140 \mathrm{pmol} / \mathrm{L}$ while post-meal insulin reached 840 $\mathrm{pmol} / \mathrm{L}$ [67]. Fasting insulin of $>85 \mathrm{pmol}(12.2 \mathrm{mIU} / \mathrm{L})$ has been proposed as a cutoff to define hyperinsulinemia and is sufficient to mark the pathological state of metabolic syndrome [68]. In all conditions, insulin levels are thought to be at least approximately 10 times higher in the pre-hepatic portal circulation and in the pancreas $[69,70]$. Conceptually, hyperinsulinemia can be defined as excess insulin relative to what is required to maintain normal glucose. Hyperinsulinemia can manifest as an elevation in basal/fasting circulating insulin and/or as a potentiation of post-prandial insulin secretion [71,72], and can result from insulin hypersecretion or reduced systemic insulin clearance, or both [73-76]. It is critical to understand which type of hyperinsulinemia is being studies when examining correlations with and causal effects on various (patho)physiological parameters.

Relative insulin insufficiency defines diabetes, but long before diagnosis of type 2 diabetes mellitus (T2DM), excess insulin predicts the people who will progress to disease [77,78]. The coincidental timing of hyperinsulinemia, insulin resistance, and obesity has led to 'chicken and egg' questions and extensive debate $[2-4,79]$. Conventional dogma places excess adiposity and insulin resistance as initial causes, with hyperinsulinemia as a consequence. The commonly accepted model holds that obesity causes hyperinsulinemia via insulin resistance. The insulin resistance is thought to arise primarily from the spill over of lipids into liver, muscle, and other tissue (i.e., ectopic lipid deposition), from adipose tissue that has exceeded its capacity for storage $[4,41,80]$. The obesity-induced insulin resistance is then thought to lead to hyperglycemia which then drives the pancreatic $\beta$-cells to secrete more insulin to maintain glucose homeostasis, causing hyperinsulinemia. However, clinical observations cast doubt that this paradigm is applicable in all cases, especially when hyperglycemia is often one of the last clinical features in the progression from obesity to T2DM and when insulin resistance is circularly defined as unexplained hyperinsulinemia [81]. Basal hyperinsulinemia has been documented to occur prior to insulin resistance, obesity and/or hyperglycemia [24,71,82-92]. Analysis of 1,168 non-diabetic adolescents and adults found that the upper tertile of insulin hypersecreting individuals showed significantly increased fat mass, worse lipid profile and impaired glucose tolerance independent of clamp-measured insulin resistance, compared to the lower tertiles [93]. Obesity is associated with increased basal and post-prandial insulin secretion even in subjects without insulin resistance [94]. Moreover, injected insulin is sufficient to induce insulin resistance in humans, compared with glycemia matched controls [95]. Epidemiological studies show that children with hyperinsulinemia had an increased risk of developing obesity later in life [82,92]. These observations cast doubt on the primacy of classically-defined insulin resistance in the pathogenesis of obesity and T2DM. From an endocrinological perspective, hormones are known to desensitize their receptors and post-receptor signaling processes when present in excess. Genetic downregulation of insulin production illustrated that hyperinsulinemia is a cause, and not just the consequence, of insulin resistance and elevated fasting glucose in old age [44]. Revisiting the concept of insulin resistance is beyond the scope of this review, but will be the subject of a forthcoming article.

The human genetics of obesity are complex but provide insight into cause-and-effect and the role of specific components of insulin signaling. Genome-wide association study (GWAS) studies have shown that the vast majority of the common variation underlying body mass index (BMI) is related to food intake centers in the brain [96]. FTO (FTO alpha-ketoglutarate dependent dioxygenase) is associated with hyperinsulinemia, among many other possible mechanisms [97]. INSR and other components of the insulin signaling pathway are associated with lipid and adiposity-related traits (www.ebi.ac.uk/gwas). Moreover, the INS locus itself is associated with anthropometric traits including height, birth weight, fat-free mass, and waist-hip ratio, 
in addition to both type 1 diabetes mellitus (T1DM) and T2DM (www.ebi.ac.uk/gwas). The INS locus is complex, and how these polymorphisms affect insulin secretion remain unclear, but are beginning to be investigated. Mendelian randomization studies support a causal role for genetically driven glucosestimulated hyperinsulinemia in obesity [98], although studies also support a causal contribution of BMI to fasting insulin and insulin resistance [99]. It is likely that there is bi-directional causality and the results depend on which single-nucleotide polymorphisms and which anthropomorphic traits are chosen for analysis. Studies of rare human genetic conditions also support a causal role for insulin action in obesity. For example, increased global insulin sensitivity in humans with phosphatase and tensin homolog (PTEN) mutations causes obesity [100], whereas humans with INSR loss-of-function mutations (e.g., Donohue syndrome) have intrauterine growth restriction and reduced subcutaneous fat [101]. Together, these studies point the possibility that genetic variation in insulin and/or insulin signaling contributes to human obesity.

Multiple environmental and inherited factors can drive insulin hypersecretion and reducing these burdens has been shown to prevent or ameliorate disease. Thomas et al. [92] and Corkey [102] proposed environmental/diet factors that can drive primary hyperinsulinemia. Reducing fasting insulin with low carbohydrate diets, caloric restriction, or time-restricted feeding improves insulin sensitivity in mice and humans and may lead to T2DM remission [103-106]. Bariatric surgery simultaneously corrects hyperinsulinemia and diabetes, independent of weight loss, insulin sensitivity, or glucose [3]. However, even clinical studies with sensitive measures are often correlative, making direct experimental manipulation of insulin the most robust way to test the hypothesis that hyperinsulinemia drives chronic diseases, including diabetes, obesity, and even cancer. Indeed, blocking insulin secretion with diazoxide or octreotide causes weight loss in both rat model and human studies, supporting a causal role in obesity for excess insulin [107-112]. Clinical trials have shown that prolonged elevation of exogenous long-acting insulin analogues causes weight gain [113]. Collectively, there is strong clinical evidence in humans, both loss-of-function and gain-of-function studies, that support a primary, causal role for hyperinsulinemia in obesity and associated traits [2,71,79,92,102].

Complementing clinical studies, engineered mouse models provide genetic certainty that manipulation of insulin production causes changes in body weight and adiposity [2]. In an initial study, Mehran et al. [20] found that mice with only one allele of Ins1, which significantly reduced fasting insulin levels, were protected from high-fat diet-induced obesity and adipocyte hypertrophy compared to control mice with two alleles of Ins1 in an Ins2-null genetic background. Energy expenditure was increased, but there was no difference in measured food intake [20]. Follow-up studies identified upregulation of oxidative phosphorylation complex proteins and uncoupling protein 1 in white adipose tissue [114]. Templeman et al. [30,115] made similar observations by modulating Ins 2 gene dosage in mice without Ins1. When experimental Ins ${ }^{-1-} ; \operatorname{Ins} 2^{+/-}$mice were implanted with insulin releasing pumps, body weight, white adipose tissue mass and adipose tissue hypertrophy were partially restored [30]. D'Souza et al. [116] showed that obesity driven by leptin deficiency also requires hyperinsulinemia. Page et al. [117] used a conditional Ins2 partial ablation and the resulting modest reduction in insulin secretion to induce weight loss in mice that were already obese. In all of these experiments, changes in circulating insulin that were too small to adversely affect glucose homeostasis were nonetheless able to significantly alter adiposity. Our studies agree with work from other groups showing that mouse models with reduced insulin secretion are protected from diet-induced obesity [118] and that Insr deficiency in adipose tissue prevents diet- and age-induced obesity $[26,59,119,120]$. Multiple lines of evidence demonstrate that maximal adipocyte hyperplasia and hypertrophy require fully intact insulin action.

The biochemical rationale for insulin-driven obesity and insulin resistance are established. Insulin is a robust stimulator of lipid transport into adipocytes, adipocyte differentiation and a potent inhibitor of lipolysis in adipose tissue [121]. The specific mechanisms by which hyperinsulinemia affects adiposity remain understudied. One of the main effects of insulin on adipocytes is to promote lipogenesis through stimulation of fatty acid uptake and triglyceride synthesis $[2,122,123]$. Insulin can also inhibit lipolysis and induce the expression of transcription factors such as CCAAT/enhancer-binding protein $\beta$ to modulate lipid uptake and storage $[2,124,125]$. More acute, inducible reduction of insulin production in adult mice had a specific effect on visceral adipose tissue and a reduction in the protein abundance of the human lipodystrophy gene, caveolae associated protein 1 (Cavin1) [117]. Therefore, excess insulin signaling in adipocytes can lead to excess fat accumulation and to obesity.

Insulin may also regulate peripheral lipid metabolism 
through the brain $[119,124,125]$; however, the actions of central insulin signaling on food intake and body weight remain controversial. For instance, insulin administration by intracerebroventricular injection increased fat mass and adipocyte size in some studies [26,119], but decreased food intake and body weight in others [126-130]. Moreover, some researchers observed that hypothalamic Insr deletion was accompanied by hyperphagia and fat mass increase [126,131,132], while some found the deletion caused a reduction in white adipose tissue mass [130]. The reasons for these inconsistencies are unclear. Likely, the direction of the effects depends on the specific brain regions in which insulin signaling is inhibited or activated $[124,126]$.

\section{EFFECTS OF HYPERINSULINEMIA ON INFLAMMATION}

Inflammation is associated with metabolic dysfunction such as obesity and insulin resistance [133]. Several studies suggest that obesity-associated, chronic, low-grade inflammation can cause insulin resistance in metabolic tissues like liver, muscle, and adipose tissues [134-136]. However, insulin resistance can also precede inflammation [137], can occur independently of inflammation [138], and anti-inflammatory treatments have not been shown to cause weight loss in humans. The root cause and the ultimate consequences of inflammation in context of metabolic health remains to be fully understood. Nevertheless, there is a strong association between hyperinsulinemia and chronic low-grade inflammation. Modest hyperinsulinemia in experimental animals is sufficient to cause adipose tissue inflammation [139]. Mice with both chronically and acutely reduced insulin production exhibit a gene expression profile that suggests impaired innate immunity in adipose tissue [20,117]. Insulin infusion during euglycemic hyperinsulinemic clamp increases pro-inflammatory interleukin 6 (IL-6), tumor necrosis factor alpha (TNF- $\alpha$ ), and monocyte chemoattractant protein-1 (MCP-1) in human serum and adipose tissue [140-143]. Thus, both human and mouse studies support the concept that hyperinsulinemia is necessary and sufficient to promote inflammation.

Hyperinsulinemia can contribute to tissue-specific inflammation in multiple ways. For example, we and others have shown that hyperinsulinemia leads to hypertrophic and unhealthy adipocytes $[20,119,144,145]$, which can attract macrophages and other immune cells [146-149]. Hyperinsulinemia may also promote inflammation by direct effects on immune cells. Insr mRNA is expressed in multiple immune cell types, based on single-cell RNA sequencing data (Fig. 2A), suggesting that at least some effects of hyperinsulinemia may be direct. Previous studies have identified INSRs mRNA or protein in T-cells, Bcells, neutrophils, monocytes, macrophages, and natural killer (NK) cells [150-153]. INSR expression in murine T-cells increased with activation $[151,152]$, suggesting a role in T-cell function. T-cells with specific Insr gene knockout exhibit reduced production of interferon gamma (IFN $\gamma$ ), IL-4, and IL10 upon activation, as well as diminished cytotoxicity [151, 153]. Insulin, acting through INSR, is also required for maximal T-cell proliferation and its loss leads to apoptosis sensitivity and defective differentiation toward the T helper cell 1 (Th1) and Th17 lineages $[151,154]$. Similarly, AKT inactivation limits proliferation and the production of IL-2, IL-4, and IFN $\gamma$ in $\mathrm{CD}^{+}$T-cells [155]. Collectively, these studies suggest that insulin signaling regulates $\mathrm{T}$-cell cytokine production and proliferation. T-cell activation requires glucose and glutamine metabolism [153,156-158]. Therefore, it is possible that insulin signaling controls activated $\mathrm{T}$-cell functions through regulation of glucose metabolism (e.g., stimulating glycolysis and regulating glucose or amino acid transporters expression on $\mathrm{T}$ cells). Although no studies have directly addressed how hyperinsulinemia affects T-cell function, it seems likely based on the above evidence that hyperinsulinemia would be pro-inflammatory. Obesity-induced hyperinsulinemia has been correlated with reduced regulatory T-cell proportions $[153,159,160]$. Both in vivo and in vitro studies showed that hyperinsulinemia reduced the regulatory T-cells' ability to produce IL-10, which in turn impairs their ability to suppress TNF- $\alpha$ production in macrophages [153]. The effects of AKT/PI3K signaling on regulatory T-cell suppressive activity have been reported to be positive in some studies $[155,161]$ and negative in others $[155$, 162]. Collectively, the available literature suggests that insulin and downstream signaling may have important and direct effects on both cytotoxic and regulatory T-cells.

Insulin signaling also affects innate immune cells. Macrophages are responsible for detecting, destroying and engulfing pathogens and macrophages can polarize along a spectrum of M1 to M2 [163,164]. So called 'M1 macrophages' produce proinflammatory cytokines such as TNF- $\alpha$, IL-6, and IL- $1 \beta$ which kill pathogens or tumor cells. 'M2 macrophages' produce antiinflammatory cytokines like IL-10 and transforming growth factor beta 1 (TGF- $\beta$ ), which heal wounds and resolve inflam- 

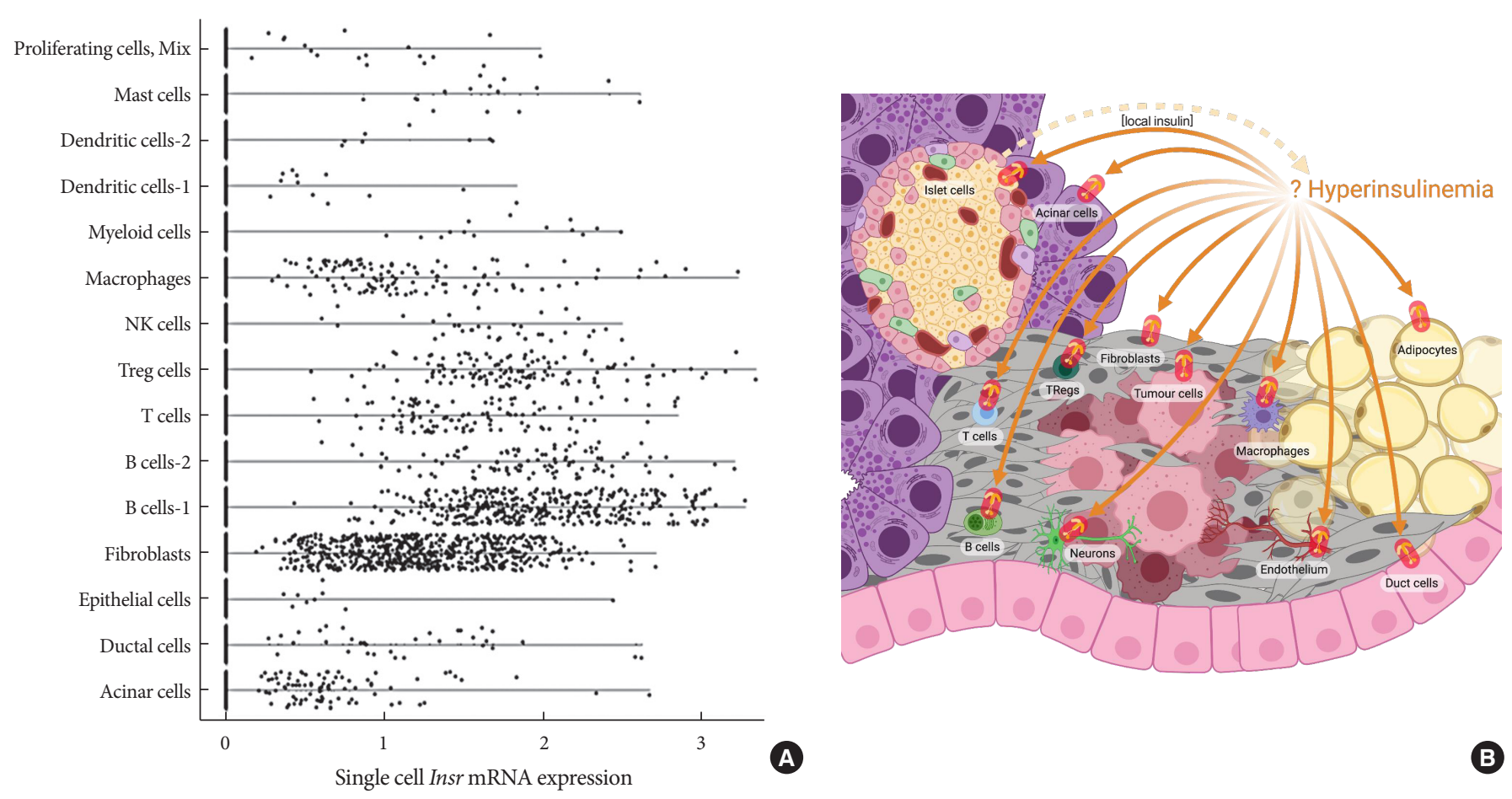

Fig. 2. Possible cellular targets of hyperinsulinemia in pancreatic cancer. (A) Violin plot showing insulin receptor (Insr) expression in pancreatic cells and immune cells. The data is based on single-cell gene expression analysis of mouse pancreas in $P t f 1 a^{\text {CreER}}$; LSL-Kras ${ }^{\mathrm{G} 12 \mathrm{D}}$; Ins1 ${ }^{-/-}$genetic background generated using 10x Genomics. Background mRNA contamination was cleaned by R packages SoupX and the single-cell gene expression data was analyzed by Seurat 4.0 (Satija Lab). (B) Possible cellular targets of hyperinsulinemia in pancreatic cancer initiation and/or progression.

mation $[136,163,164]$. Macrophages are known to modulate both insulin secretion [165] and tissue insulin sensitivity [136, 166,167]. Insulin signaling within macrophages has been extensively studied $[168,169]$. Macrophages express all components of insulin signaling cascade [170,171], and when Insr or Akt2 were deleted, macrophages shifted towards an anti-inflammatory phenotype with reduced IL-6, IL- $1 \beta$, and TNF- $\alpha$ [170-173]. However, studies employing PI3K or AKT overexpression, PI3K knockout, or deletion of PTEN and Src homology 2-containing inositol 5'-phosphatase have also implicated $\mathrm{PI} 3 \mathrm{~K} / \mathrm{AKT} / \mathrm{mTOR}$ signaling in M2 polarization [173-179]. These inconsistencies in M1/M2 polarization may be related to AKT and mTOR isoform specificity $[173,174,180]$. Moreover, given that PI3K/AKT/mTOR signaling can be stimulated by many ligands besides insulin, for example TGF- $\beta$, IL-10, and bone morphogenetic protein $7[174,180]$, the role of this signaling cascade in macrophage function may be context dependent.

\section{HYPERINSULINEMIA AND CANCER}

Interest has grown recently around the possibility that excess insulin, a consequence of unhealthy diets and lifestyles, may have cancer-promoting effects. Insulin is a powerful mitogen and survival factor for virtually all cell types $[23,32,181]$. While insulin's close relative IGF1 has been extensively studied for its roles in many cancers, studies on the potential role of insulin have lagged behind. Some epidemiological studies report increased cancer risk in patients receiving exogenous long-acting insulins as diabetes therapy [182-187], but these findings were controversial and subsequent studies have failed to find a consistent association [188-191]. Interest has now shifted towards the role of endogenous insulin in cancer risk. Despite correlative human data associating high levels of insulin with multiple types of cancer, the cause-and-effect relationship had not previously been established for any cancer [192-195].

Obesity and diabetes are risk factors for many different types of cancers [5,196-200]. In 2012, combined effects of high BMI and diabetes were responsible for $5.7 \%$ of cancer cases [201]. 
Broken down by cancer type, $16.5 \%$ to $18.8 \%$ of liver cancer, $13.1 \%$ of pancreatic cancer, $7.2 \%$ of breast cancer, $31.3 \%$ of endometrial cancer, $28.7 \%$ to $29.5 \%$ oesophageal cancer, and $18 \%$ to $21.3 \%$ of kidney cancers have been attributed to obesity and diabetes [201]. Compared to healthy people, patients with diabetes have 1.57-fold increased risk of death from cancer and more specifically, they were associated with about 2.34 -fold, 8.47-fold, and 4.2-fold increased risk of deaths from pancreas, liver, and breast cancers, respectively [200,202]. Obesity is associated with $14 \%$ in colorectal and 35\% increase in breast cancer-specific mortality, respectively $[203,204]$. Populations with diabetes and obesity are increasing rapidly [205-208] and the percentage of cancer cases attributable to obesity and diabetes increased $20 \%$ and 30\%, respectively, between 1980 and 2002 [201]. Obesity and diabetes are also associated with increased cancer mortality [199,200,202,209-211]. There is an urgent need to identify the underlying mechanisms that link cancers to obesity and diabetes.

Hyperglycemia, hyperinsulinemia, increased inflammation and dyslipidemia usually accompany obesity and diabetes and those metabolic changes are considered as factors causing increased risks of cancers morbidity and mortality [5,209,211, 212]. For instance, hyperglycemia may provide extra-glucose to cancer cells to maintain their rapid proliferation and meet the demand for biomass production. Hyperglycemia can cause overproduction of advanced glycation end-products and reactive oxygen species, which can cause DNA damages [209,212]. Moreover, dysregulation of leptin and adiponectin production in adipocytes that is associated with obesity and diabetes can also affect cancer cells growth and survival [209,212]. Here, however, we are focused on hyperinsulinemia as a potential driver of increased cancer incidence and mortality. Previous scholarship has thoroughly reviewed other possible mechanisms [209,212].

Hyperinsulinemia is associated with cancer mortality independently of diabetes, obesity, and metabolic syndrome [213, 214]. Insulin is a well-established growth factor for many cell types, including pancreatic cancer cells and their likely precursors [215]. In addition to pancreatic cancer (see below) [213, 216-219], people with hyperinsulinemia also had increased risk of breast [197,220-223], colorectal [196,224,225], prostate [226], endometrial [227,228], liver [198], and ovarian cancers [229], regardless of BMI. Hyperinsulinemia was associated with a 2 -fold risk of cancer death [196,211,230,231]. This increase of cancer mortality is also observed in people with nor- mal body weight if they had hyperinsulinemia [214]. Therefore, hyperinsulinemia is associated with increased risk of both cancer incidence and death. However, unlike hyperglycemia, there is no widely accepted insulin concentration to define hyperinsulinemia, so it is difficult to compare across studies. Nevertheless, the rationale to study the contribution of hyperinsulinemia to cancer is strong.

\section{THE INSULIN RECEPTOR, INSULIN SIGNALING AND CANCER}

Insr expression levels and isoform splicing have been investigated for their roles in cancer. There are two isoforms of INSR, INSR-A, and INSR-B. INSR-B includes the exon 11, which is not present in INSR-A $[39,40]$. INSR-A/INSR-A homodimers, INSR-A/IGF1R heterodimers, and INSR-B/IGF1R heterodimers can bind to insulin, IGF1, and IGF2; however, INSR-B/ INSR-B homodimers can only bind to insulin when comparing the ligands at physiological concentrations $[39,40]$. INSRA has a higher affinity to insulin than INSR-B. INSR-A is believed to mediate more of the mitogenic and anti-apoptotic effects of insulin while INSR-B is believed to carry more metabolic effects $[39,40]$. INSR-A is believed to be the isoform that is predominantly upregulated and overexpressed during cancer development $[5,39,40,211]$. The increase of INSR-A/INSR$\mathrm{B}$ ratio has been found in breast [46,232-236], prostate [237239], endometrial [240,241], colon [242], and lung cancers [242-244]. The mechanism of how cancer cells overexpress INSRs (especially INSR-A) is still unknown but some studies suggest that the transcription of Insr maybe dysregulated. Two transcription factors, high mobility group AT-Hook 1 and specificity protein 1 which positively regulate Insr expression, were found upregulated in some cancers [245-248]. On the other hand, tumor protein p53 (TP53), which is the negative regulator of Insr, frequently has loss-of-function mutation in cancers [249]. Some microRNAs that are known to be involved in regulating Insr and IgfIr are also dysregulated in certain cancers, although additional mechanistic studies are required [250,251]. Hyperinsulinemia can cause INSR internalization, which decreases the number of INSRs available on the cell membrane for binding the insulin ligand; however, some studies have found that breast cancer cells lose their sensitivity to hyperinsulinemia-induced INSR downregulation [46,234]. Furthermore, the increased INSR-A to INSR-B ratio was positively correlated with hyperinsulinemia, while the decreased 
INSR-A to INSR-B ratio was associated with low insulin levels after fasting or after bariatric surgery $[40,252,253]$. One of the mechanisms for this hyperinsulinemia-induced INSR-A upregulation could involve the insulin-induced degradation of splicing factor, which can shift INSR-A to INSR-B ratios $[40,254]$. Multiple drugs were designed to targeted IGF1R and INSR. However, the potential for insulin and IGF1 to bind both receptors complicates results from clinical studies and highlights the need for further understanding of receptor regulation in cancer cells $[40,209,255]$. Anticancer therapies that target both receptors at the same time or target molecules which are downstream the merged signaling pathway may be more effective.

Major components of the insulin signaling pathway (e.g., RAS, AKT, PI3K) are frequently mutated in cancer [41,256]. Moreover, phosphatases like PTEN which negatively regulate insulin signaling, are well-known as tumor suppressors and are also frequently mutated in cancers $[41,256]$. The frequent mutations in insulin signaling pathway can affect cell proliferation and survival in multiple steps. When insulin binds to INSR, it causes receptor autophosphorylation and activation of the $\mathrm{PI} 3 \mathrm{~K} / \mathrm{AKT} / \mathrm{mTOR}$ signaling cascade [42]. AKT can directly phosphorylate BCL2 associated agonist of cell death and caspase-9 which inhibit the mitochondrial apoptosis pathway and promote cell survival $[41,256]$. AKT can also indirectly inhibit apoptosis and cause cell-cycle arrest by phosphorylating and inhibiting FOXO, as FOXO can promote Bcl-2-like protein 11 and induce proapoptotic cytokine Fas ligand expression [256]. MDM2 proto-oncogene is also phosphorylated by AKT and inhibits the tumor suppressor TP53 [257]. Therefore, insulin can provide survival signals to cancer cells to escape cell-cycle arrest and apoptosis. In addition, insulin also supports cancer cell proliferation. When mTOR is phosphorylated by AKT, it activates substrates S6 kinase 1 and eIF4E-binding protein 1, which regulate mRNA translation initiation and progression to control protein synthesis and cell growth [42]. Moreover, tumor cells generally need to take up more glucose to generate biomass and support their repaid growth, so hyperinsulinemia may also contribute to cancer development through making more glucose transporters available in tumor cell surface to transport glucose. In addition to PI3K/AKT/mTOR signaling pathway, hyperinsulinemia can also promote cancer development through MAPK/ERK pathway which is important for cell proliferation and RAS is frequently mutated to be constitutively active in cancer cells $[41,43,211,258]$. RAS needs to be farnesylated and anchored at plasma membrane before it activated by SOS, which is a guanine nucleotide exchange factor [259]. Insulin can phosphorylate and active farnesyltransferase which is the enzyme involved in isoprenylation of RAS [259263], so hyperinsulinemia may augment the amount of farnesylated RAS available for GTP loading in response to stimulation by other growth factors. As a result, hyperinsulinemia may promote cancer cell growth and prevent cancer cell death through both PI3K/AKT/mTORC and MAPK/ERK signaling cascades.

\section{HYPERINSULINEMIA AND PANCREATIC CANCER}

Pancreatic cancer, more specifically exocrine pancreatic cancer or pancreatic ductal adenocarcinoma (PDAC), is the 4th most common cause of cancer death [264]. Risk factors for pancreatic cancer include obesity, T2DM, pancreatitis, smoking, and family history [265-271]. As obesity and diabetes rates skyrocket, these are becoming even more ominous risk factors [265], with obesity predicted to overtake smoking as the leading preventable cause of cancer [272]. T2DM was shown to be an independent risk factor for pancreatic cancer in many studies [273-278] and some authors have implicated hyperglycemia in cancer pathogenesis $[279,280]$. However, inferring causality for this observation is further complicated by the fact that PDAC itself and PDAC treatment regimens can cause diabetes [281-283]. Nevertheless, a Mendelian randomization study pointed to causal roles for BMI and fasting insulin, but not T2DM or dyslipidemia, in PDAC [284].

The pancreas is anatomically unique due to its close proximity to the source of circulating insulin. After insulin is secreted from $\beta$-cells, it is first transported through the portal circulation to the liver, where over $50 \%$ of insulin is absorbed [76]. As a result, the local pancreatic insulin concentration is approximately 10 times higher than what is found in the post-hepaticcirculation $[69,70]$. Insulin has potent mitogenic and antiapoptotic actions on primary and transformed cells from the endocrine pancreas, from both humans and rodents [20,181, 285,286]. Previous studies have shown that there were more acinar cell mitoses around islet cells compared to other pancreatic cell types, and T1DM patients had smaller number of acinar cells [287-289]. Pre-clinical islet transplant experiments have suggested that local hyperinsulinemia alone, at levels that do not cause hypoglycemia, can promote neoplasia [290,291]. 
Clinical and epidemiological studies showed hyperinsulinemia was associated with increased risk of cancer, including PDAC. For example, in a 16 years follow-up study for male Finnish smokers, researchers found insulin concentration in the highest vs lowest quartile predicted a 2 -fold increased risk for pancreatic cancer and the associations were stronger when the follow-up was longer than 10 years [219]. Retrospective studies show that metformin, which reduces hyperinsulinemia, may lower pancreatic cancer risk in animals [292] and in patients by up to $60 \%$ [182,293-297], although the magnitude of this effect is controversial $[298,299]$ and it is unclear whether metformin acts via lowering insulin or modulating AMP-activated protein kinase (AMPK) or another mechanism [300-303]. Thus, multiple groups have proposed that excess insulin levels contribute to pancreatic cancer initiation or progression [304308], but this possibility had never been formally tested before our recent work [31], in part because animal models with precise control of insulin secretion or action were not available.

In vivo animal studies are required to directly test for causality in the hyperinsulinemia-cancer hypothesis. In our recent study, we demonstrated hyperinsulinemia contributes causally to pancreatic cancer development using a unique mouse model [31]. We again used female mice with lower fasting insulin without affecting the glucose homeostasis $\left(\operatorname{Ins} 1^{+/-} ; \operatorname{Ins} 2^{-/-}\right.$compared to Ins $1^{++}$; Ins $2^{--}$) $[20,30]$ that also expressed commonly used pancreatic cancer susceptibility alleles that reflect human disease genetics (Ptf1 $a^{\mathrm{CreER}}$; LSL-Kras ${ }^{\mathrm{G} 12 \mathrm{D}}$ ) [258]. We fed all groups of mice a hyperinsulinemia-inducing high-fat diet. We found there were significant reductions of pre-pancreatic cancer lesions and fibrogenesis in mice with reduced insulin secretion, demonstrating that endogenous hyperinsulinemia contributes to pancreatic cancer development [31]. These observations are consistent with other, less direct models designed to test whether hyperinsulinemia accelerates the initiation and/or progression of other types of cancer. The next step will be to determine which of the main Insr expressing cell types contribute to the effects of hyperinsulinemia on pancreatic cancer initiation and/or progression (Fig. 2B).

\section{TESTING THE INSULIN-CANCER HYPOTHESIS OUTSIDE OF THE PANCREAS}

Insulin signaling connects with many signaling networks known to drive breast cancer initiation and progression (Fig. 3). Epidemiological evidence demonstrates that both obesity and diabetes are associated with breast cancer incidence and prognosis. Clinically, breast cancer is categorized into three subtypes, which dictate treatment courses and prognoses. More than $70 \%$ of breast cancers ( $>150,000$ cases/year) overexpress the estrogen receptor (ER) and/or progesterone receptor $(\mathrm{PR})$ and these are frequently diagnosed after menopause [309]. Half of the remaining tumors express the human epidermal growth factor receptor 2 (HER2). The other half of cases lack all three receptors and are classified as triple negative [309]. The obesity-specific risk for breast cancer is greatest for the ER/PR-positive subtype [310]. Breast cancer risk increases by $12 \%$ (relative risk [RR], 1.12) for every $5 \mathrm{~kg} / \mathrm{m}^{2}$ increase in BMI [269]. Because obesity is a shared risk factor between diabetes and breast cancer, most studies evaluate cancer risk in patients with diabetes after adjusting for BMI. Data from the Nurses' Health Study suggest that women with diabetes have an elevated risk for breast cancer (hazard ratio [HR], 1.17) [311], which was confirmed in a more recent meta-analysis (summary relative risk [SRR], 1.16) [312]. These significant relationships remained after adjusting for BMI. A different study found that diabetes was associated with increased breast cancer-specific mortality (RR, 1.27) $[312,313]$ that was not explained by obesity. Both obesity and diabetes are associated with advanced breast cancer at diagnosis [310,314,315], including larger, higher grade tumors and lymph node involvement $[310,314,316]$. In each study that found a relationship between breast cancer and either obesity or diabetes, the link was strongest in postmenopausal women [269,312,316-319]. Before menopause, obesity and diabetes each associate with a decreased risk for breast cancer [312,317], but the mechanisms behind this paradox are unclear. Importantly, the associations between diabetes and breast cancer are specific to T2DM, as individuals with T1DM do not face increased risk or mortality [312]. This observation implies that one or more of the major pathophysiological differences between T2DM and T1DM, such as hyperinsulinemia or hyperlipidemia (but not hyperglycemia) play causal roles.

Two underlying drivers of the obesity-cancer relationship may be metabolic dysfunction and adult weight gain. Three studies found similar links between metabolic health and breast cancer risk independent of obesity. In a prospective cohort study, women with a normal weight (BMI $\left.<25 \mathrm{~kg} / \mathrm{m}^{2}\right)$ and one or more features of metabolic disease (e.g., high waist circumference, elevated blood pressure, and/or diabetes) had a similarly elevated risk for postmenopausal breast cancer (HR, 


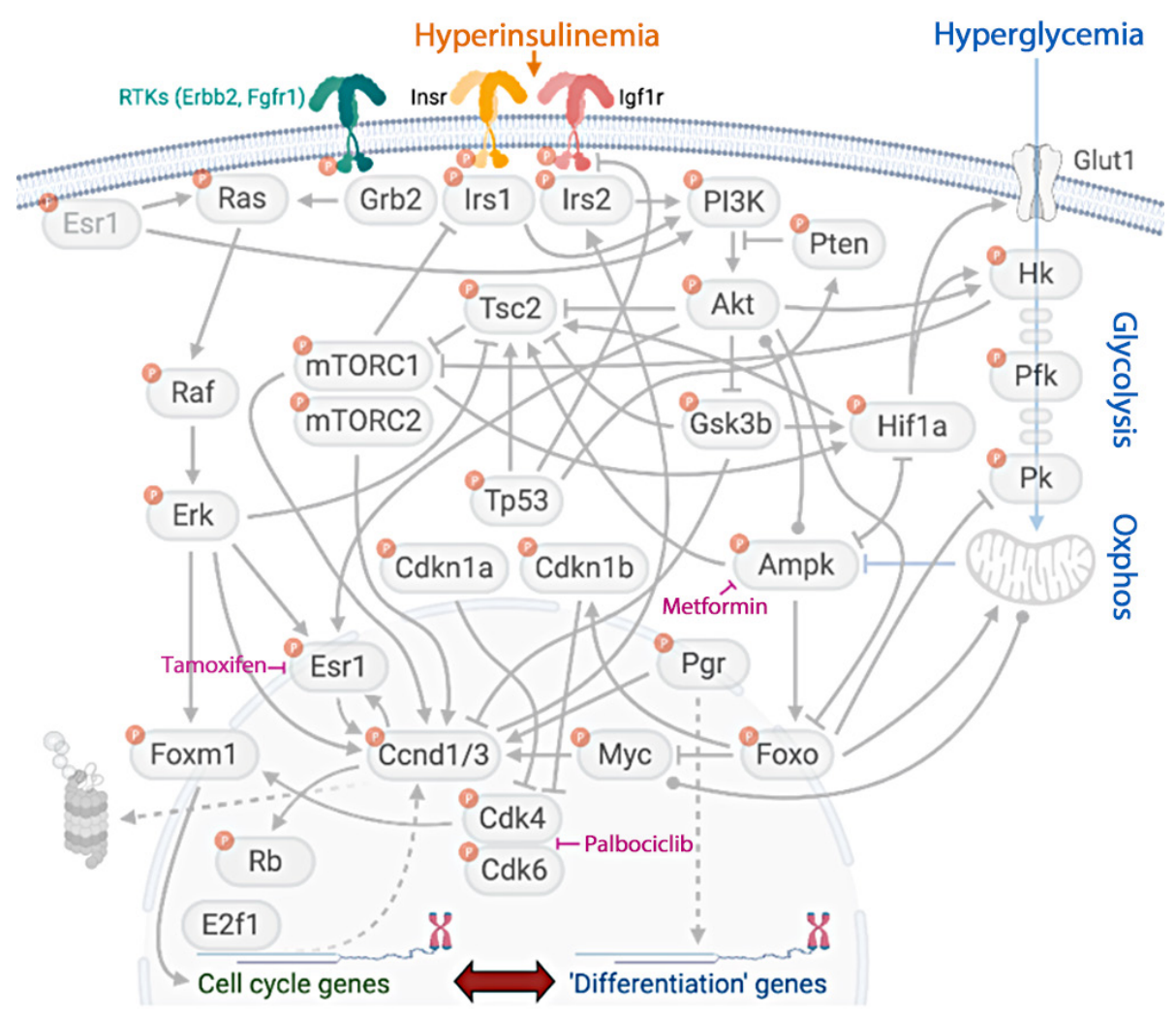

Fig. 3. Multiple links between insulin signaling and breast cancer. Insulin/Igf1 receptor signaling interacts with master regulators of breast cancer cell fate, including estrogen receptor signaling, core cell-cycle regulators, and metabolism. Virtually all proteins in this signaling network are regulated by phosphorylation. RTK, receptor tyrosine kinase; Erbb2, proto-oncogene Neu/Her2; Fgfr, fibroblast growth factor receptor; Insr, insulin receptor; Esr1, estrogen receptor 1; Grb2, growth factor receptor-bound protein 2; Irs, insulin receptor substrate; PI3K, phosphoinositide 3-kinase; Tsc2, tuberous sclerosis complex 2; Pten, phosphatase and tensin homolog; Glut1, glucose transporter 1; Hk, hexokinase; mTORC, mammalian target of rapamycin complex; Erk, extracellular signal-regulated kinase; Tp53, tumor protein p53; Gsk3b, glycogen synthase kinase 3b; Hifla, hypoxia-inducible factor 1a; Pfk, phosphofructokinase; Pk, pyruvate kinase; Cdkn1, cyclin-dependent kinase inhibitor-1; Ampk, AMP-activated protein kinase; Pgr, progesterone receptor; Foxm1, forkhead box M1; Ccnd1/3, cyclin-dependent kinase 1/3; Myc, myc oncogene; Foxo, forkhead family box $\mathrm{O}$; Cdk, cyclin-dependent kinase; Rb, retinoblastoma; E2f1, E2F transcription factor 1.

1.26) to women who were metabolically healthy but had overweight or obesity (HR, 1.24) [320]. Another recent study found that obesity, regardless of metabolic health, associated with increased risk of breast cancer, with the highest risk seen in metabolically unhealthy women with obesity (HR, 1.62) [321]. A third study found that women classified as metabolically unhealthy based on homeostatic model assessment for insulin resistance or fasting insulin had an elevated risk for breast cancer regardless of BMI [197]. The most recent, large, prospective cohort study reported elevated risks for breast (HR, 1.16) and endometrial cancer $(\mathrm{HR}, 2.94)$ in women with overweight or obesity even after adjusting for metabolic status [322]; however, risks were greatest in the presence of metabolic disease and obesity [315]. Together, these studies suggest that while metabolic dysfunction contributes to cancer, it may not be the only mechanism. Women who transitioned from a "lean" BMI $(<25$ $\mathrm{kg} / \mathrm{m}^{2}$ ) to either overweight or obese faced an increased risk of breast cancer (HR, 1.36) compared with women who had an elevated BMI as young adults and did not gain more than $5 \%$ weight over approximately 13 years of follow-up [316]. In addition, a meta-analysis estimated that every $5 \mathrm{~kg}$ of weight gained increased the risk for breast cancer by $11 \%$ (SRR, 1.11) and endometrial cancer by 39\% (SRR, 1.39) [323].

As with obesity, women with diabetes may have a greater risk of breast cancer recurrence compared to women without diabetes (odds ratio [OR], 2.21) [314]. However, whether dia- 
betes increases breast cancer-specific mortality remains controversial. A recent Mendelian randomization study that investigated the genetic predisposition to T2DM, as well as predicted fasting insulin and glucose, did not find a causal association with any variable and breast cancer risk [324], but this does not preclude roles for non-genetic drivers of hyperinsulinemia and hyperglycemia. Some studies [325] including the Women's Health Initiative (WHI) $[315,326]$, do not support a link between diabetes and death specifically from breast cancer. In contrast, one large prospective study found that diabetes increased the risk for death from breast cancer in women (RR, 1.16) and in men (RR, 4.20) [200] after adjusting for BMI. Similarly, a smaller population-based study found that diabetes predicted a shorter breast cancer specific survival (HR, 1.53) for women with early stage breast cancer, which was also independent of BMI [327]. Consistent with breast cancer, obesity and diabetes are strongly associated with the incidence and mortality of endometrial cancer [328-330]. Obesity is thought to be responsible for over half of endometrial cancer diagnoses [269,331], with risk increasing by $50 \%(R R, 1.50)$ for every 5 $\mathrm{kg} / \mathrm{m}^{2}$ increase in BMI [332]. Data from the WHI suggests that elevated BMI increases the risk for endometrial cancer by $76 \%$ (HR, 1.76) [333]. Diabetes increases the risk for endometrial cancer by 2-fold [328], and a Mendelian randomization analysis estimated a small increase (OR, 1.08) in the risk associated with both diabetes and predicted fasting insulin [324]. However, among a total of nine studies examining diabetes and endometrial cancer risk, only four studies [328,334-336] adjusted for BMI with two $[328,336]$ reporting a significant association independent of BMI. Thus, for endometrial cancer, the data are moderate that diabetes is associated with risk independently of obesity. Unlike breast cancer, T1DM is associated with endometrial cancer risk (SRR, 3.15) [328], suggesting subtle but potentially important underlying differences in etiology.

Elevated fasting insulin and glucose are commonly associated with diabetes, obesity, and weight gain. Consistent with epidemiological observations, insulin and glucose have also been attributed to breast and endometrial cancer. Genetically predicted fasting insulin levels were associated with endometrial cancer risk after adjusting for BMI in a Mendelian randomization study [324]. Hyperinsulinemia associated with an increased risk for breast (HR, 1.46) [337] and endometrial cancer (HR, 2.33) [228] in the WHI study. For endometrial cancer, the risk was higher in women with hyperinsulinemia and overweight or obesity (HR, 4.30) [228]. For both cancer types, this relationship between insulin and risk was specific to nonusers of menopausal hormone replacement therapy [228,337], suggesting potential crosstalk between the insulin and estrogen signaling pathways in driving early tumor growth. A different study reported that insulin resistance, inferred from Cpeptide levels, associated with elevated breast cancer risk in women without diabetes (RR, 2.9) [338]. The potential tumor promoting mechanisms downstream of insulin are similar between breast and endometrial cancers, and include extensive cross talk with signaling networks regulated by E2 and IGF1 [338,339]. Insulin itself is a potent mitogen for cancer cells [340,341], and may potentiate signaling through ER [338,340, 342]. Data from large randomized controlled trials suggest that improving glycemic control does not reduce the risk for breast cancer [343], although this has been debated [344]. The large body of evidence linking obesity and diabetes to women's cancers has supported clinical trials that aim to address the efficacy of metformin, a widely used anti-hyperglycemic agent, against breast [345-347] and endometrial cancers [348].

Hyperinsulinemia-induced by muscle cell-specific insulin resistance in mice [349] was found to accelerate esophageal cancer [38] and breast cancer development and increase lung metastases [5,45-47,209,350]. The tissues and cancer cells from these hyperinsulinemic mice showed increased activation of INSR/PI3K/AKT signaling pathway and mammary tumor growth was independent of the IGF1 receptor [47,351]. Exogenous insulin promoted breast and colon carcinogenesis [352, 353], and diet-induced hyperinsulinemia was able to accelerate prostate cancer xenograft progression [354]. Additionally, endometrial carcinoma cell growth could be promoted by overexpressing INSR, and pancreatic cancer cells proliferated proportionally with the increase of insulin concentrations [215, 240,355]. Knocking out INSRs slowed the growth of pancreatic neuroendocrine cancer cells and melanoma cells as well as inducing the apoptosis in DNA-damaged colon cells [356-358]. Therefore, in addition to epidemiological data, the experimental mouse models provide abundant evidence that hyperinsulinemia can contribute to carcinogenesis. It remains unclear whether these effects of insulin are via cancer initiating cells, local immune cells, cancer associated stroma, or indirectly through insulin's effects on adiposity. Likely, multiple complex mechanisms are responsible for specific cancer promotion in various tissue types. Experiments where INSR is deleted from these putative cellular mediators will be required to provide clarity to this question. 
Hyperinsulinemia may also contribute to cancer development through influencing IGF1 levels. IGF1, which plays a critical role in the development of various tumors, is primarily produced in liver under the stimulation of growth hormone [212,359-362]. Similarly, insulin can also increase sex hormone and reduce sex hormone binding protein production [211, 363]. This increase of hormones such as estrogen and androgen can affect the growth of hormone-dependent tumors in the breast, prostate, and endometrium. As mentioned above, hyperinsulinemia is correlated with inflammation, which can contribute to tumorigenesis in many different aspects $[364,365]$. Together, the studies discussed above provide potential mechanisms by which hyperinsulinemia may contribute to cancer development.

As people become more aware of the cause-and-effect relationship between insulin and cancer, many more anticancer therapies targeting hyperinsulinemia have been developed and tested in animal models or in clinical trials. For instance, a recent study showed that the combination of PI3K inhibitors with kenogenetic diet or sodium-glucose transport protein 2 (SGLT2) inhibitors can effectively reduce tumor growth and increase the survival rate [366]. Also, multiple studies have demonstrated metformin could possess anti-cancer properties and there are some drugs in pre-clinical trials already [367,368]. In summary, although it is still at an early stage, our studies have demonstrated that hyperinsulinemia can contribute to tumorigenesis. It follows that lifestyle interventions or therapeutics with mild insulin suppressing actions may be useful in the prevention and treatment of some types of cancers.

\section{CONCLUSIONS}

Hyperinsulinemia is a condition associated with obesity and early stage T2DM. Recent studies have implicated hyperinsulinemia in multiple pathological conditions including insulin resistance, inflammation, obesity, and cancer. Modest inhibition of insulin production or insulin signaling is sufficient to increase of lifespans in a variety of animal models, from invertebrates to mice. Additional studies are required to elucidate the relationship between insulin and IGF during aging, as well as the shared and distinct molecular mechanisms. Conventionally, hyperinsulinemia was considered to be an adaptation to obesity-induced insulin resistance. However, evidence continues to mount that hyperinsulinemia can precede and cause obesity and insulin resistance. Animal models with reduced endoge- nous insulin secretions were protected from diet-, age-, and leptin-induced obesity, which clearly demonstrates the causal role of hyperinsulinemia in obesity. It is also clear that insulin resistance can lead to hyperinsulinemia, including at the level of the pancreatic $\beta$-cells, suggesting at least a bi- or tri-directional relationship. Future studies will be required to determine the nature of the complex vicious cycles that lead to T2DM. The metabolic importance of insulin has been long recognized but now the field is beginning to appreciate its importance in cancers. Both clinical and epidemiological studies demonstrated hyperinsulinemia is associated with increased cancer morbidity and mortality. Furthermore, direct animal studies have shown hyperinsulinemia could promote tumorigenesis, especially for pancreatic. Invertebrate models of hyperinsulinemia-induced cancer provide opportunities for powerful screens [369] that may uncover the specific molecular mechanisms involved and lead to targeted therapeutics. In summary, while insulin is essential for maintain normal life, the negative consequences of hyperinsulinemia shed light on the importance of maintaining insulin levels within a healthy range. Lifestyle interventions or therapeutics with mild insulin suppressing actions provide new opportunities to prevent and treat certain disorders like obesity, chronic inflammation and cancers.

\section{CONFLICTS OF INTEREST}

No potential conflict of interest relevant to this article was reported.

\section{ORCID}

Anni M.Y. Zhang https://orcid.org/0000-0001-9864-9411

James D. Johnson https://orcid.org/0000-0002-7523-9433

\section{FUNDING}

None

\section{ACKNOWLEDGMENTS}

None

\section{REFERENCES}

1. Banting FG, Best CH, Collip JB, Campbell WR, Fletcher AA. 
Pancreatic extracts in the treatment of diabetes mellitus. Can Med Assoc J 1922;12:141-6.

2. Templeman NM, Skovso S, Page MM, Lim GE, Johnson JD. A causal role for hyperinsulinemia in obesity. J Endocrinol 2017;232:R173-83.

3. Pories WJ, Dohm GL. Diabetes: have we got it all wrong? Hyperinsulinism as the culprit: surgery provides the evidence. Diabetes Care 2012;35:2438-42.

4. Czech MP. Insulin action and resistance in obesity and type 2 diabetes. Nat Med 2017;23:804-14.

5. Gallagher EJ, LeRoith D. Hyperinsulinaemia in cancer. Nat Rev Cancer 2020;20:629-44.

6. Ferrannini E, Galvan AQ, Gastaldelli A, Camastra S, Sironi AM, Toschi E, et al. Insulin: new roles for an ancient hormone. Eur J Clin Invest 1999;29:842-52.

7. Broughton S, Partridge L. Insulin/IGF-like signalling, the central nervous system and aging. Biochem J 2009;418:1-12.

8. Rulifson EJ, Kim SK, Nusse R. Ablation of insulin-producing neurons in flies: growth and diabetic phenotypes. Science 2002;296:1118-20.

9. Kenyon CJ. The genetics of ageing. Nature 2010;464:504-12.

10. Lok S, Johnston DS, Conklin D, Lofton-Day CE, Adams RL, Jelmberg AC, et al. Identification of INSL6, a new member of the insulin family that is expressed in the testis of the human and rat. Biol Reprod 2000;62:1593-9.

11. Ma S, Bonaventure P, Ferraro T, Shen PJ, Burazin TC, Bathgate RA, et al. Relaxin-3 in GABA projection neurons of nucleus incertus suggests widespread influence on forebrain circuits via G-protein-coupled receptor-135 in the rat. Neuroscience 2007;144:165-90.

12. Brailoiu E, Dun SL, Gao X, Brailoiu GC, Li JG, Luo JJ, et al. Cpeptide of preproinsulin-like peptide 7: localization in the rat brain and activity in vitro. Neuroscience 2009;159:492-500.

13. Ma S, Olucha-Bordonau FE, Hossain MA, Lin F, Kuei C, Liu $\mathrm{C}$, et al. Modulation of hippocampal theta oscillations and spatial memory by relaxin-3 neurons of the nucleus incertus. Learn Mem 2009;16:730-42.

14. Leroux L, Desbois P, Lamotte L, Duvillie B, Cordonnier N, Jackerott $\mathrm{M}$, et al. Compensatory responses in mice carrying a null mutation for Ins1 or Ins2. Diabetes 2001;50 Suppl 1:S1503.

15. Duvillie B, Cordonnier N, Deltour L, Dandoy-Dron F, Itier JM, Monthioux E, et al. Phenotypic alterations in insulin-deficient mutant mice. Proc Natl Acad Sci U S A 1997;94:5137-40. 16. Szabat M, Page MM, Panzhinskiy E, Skovso S, Mojibian M,
Fernandez-Tajes J, et al. Reduced insulin production relieves endoplasmic reticulum stress and induces $\beta$ cell proliferation. Cell Metab 2016;23:179-93.

17. Soares MB, Schon E, Henderson A, Karathanasis SK, Cate R, Zeitlin S, et al. RNA-mediated gene duplication: the rat preproinsulin I gene is a functional retroposon. Mol Cell Biol 1985; 5:2090-103.

18. Hay CW, Docherty K. Comparative analysis of insulin gene promoters: implications for diabetes research. Diabetes 2006; 55:3201-13.

19. Wentworth BM, Schaefer IM, Villa-Komaroff L, Chirgwin JM. Characterization of the two nonallelic genes encoding mouse preproinsulin. J Mol Evol 1986;23:305-12.

20. Mehran AE, Templeman NM, Brigidi GS, Lim GE, Chu KY, $\mathrm{Hu} \mathrm{X}$, et al. Hyperinsulinemia drives diet-induced obesity independently of brain insulin production. Cell Metab 2012;16: 723-37.

21. Fan Y, Rudert WA, Grupillo M, He J, Sisino G, Trucco M. Thymus-specific deletion of insulin induces autoimmune diabetes. EMBO J 2009;28:2812-24.

22. Kido Y, Nakae J, Accili D. Clinical review 125: the insulin receptor and its cellular targets. J Clin Endocrinol Metab 2001; 86:972-9.

23. Johnson JD, Alejandro EU. Control of pancreatic beta-cell fate by insulin signaling: the sweet spot hypothesis. Cell Cycle 2008;7:1343-7.

24. Kitamura T, Kahn CR, Accili D. Insulin receptor knockout mice. Annu Rev Physiol 2003;65:313-32.

25. Ueki K, Okada T, Hu J, Liew CW, Assmann A, Dahlgren GM, et al. Total insulin and IGF-I resistance in pancreatic beta cells causes overt diabetes. Nat Genet 2006;38:583-8.

26. Bluher M, Michael MD, Peroni OD, Ueki K, Carter N, Kahn $\mathrm{BB}$, et al. Adipose tissue selective insulin receptor knockout protects against obesity and obesity-related glucose intolerance. Dev Cell 2002;3:25-38.

27. Bluher M, Wilson-Fritch L, Leszyk J, Laustsen PG, Corvera S, Kahn CR. Role of insulin action and cell size on protein expression patterns in adipocytes. J Biol Chem 2004;279:319029.

28. Li X, Zhang L, Meshinchi S, Dias-Leme C, Raffin D, Johnson JD, et al. Islet microvasculature in islet hyperplasia and failure in a model of type 2 diabetes. Diabetes 2006;55:2965-73.

29. Dionne DA, Skovso S, Templeman NM, Clee SM, Johnson JD. Caloric restriction paradoxically increases adiposity in mice with genetically reduced insulin. Endocrinology 2016;157: 
2724-34.

30. Templeman NM, Clee SM, Johnson JD. Suppression of hyperinsulinaemia in growing female mice provides long-term protection against obesity. Diabetologia 2015;58:2392-402.

31. Zhang AM, Magrill J, de Winter TJ, Hu X, Skovso S, Schaeffer DF, et al. Endogenous hyperinsulinemia contributes to pancreatic cancer development. Cell Metab 2019;30:403-4.

32. Beith JL, Alejandro EU, Johnson JD. Insulin stimulates primary beta-cell proliferation via Raf-1 kinase. Endocrinology 2008;149:2251-60.

33. Kulkarni RN, Holzenberger M, Shih DQ, Ozcan U, Stoffel M, Magnuson MA, et al. Beta-cell-specific deletion of the Igf1 receptor leads to hyperinsulinemia and glucose intolerance but does not alter beta-cell mass. Nat Genet 2002;31:111-5.

34. Kahn CR, Bruning JC, Michael MD, Kulkarni RN. Knockout mice challenge our concepts of glucose homeostasis and the pathogenesis of diabetes mellitus. J Pediatr Endocrinol Metab 2000;13 Suppl 6:1377-84.

35. Antolikova E, Zakova L, Turkenburg JP, Watson CJ, Hanclova I, Sanda M, et al. Non-equivalent role of inter- and intramolecular hydrogen bonds in the insulin dimer interface. J Biol Chem 2011;286:36968-77.

36. Versteyhe S, Klaproth B, Borup R, Palsgaard J, Jensen M, Gray SG, et al. IGF-I, IGF-II, and insulin stimulate different gene expression responses through binding to the IGF-I receptor. Front Endocrinol (Lausanne) 2013;4:98.

37. Pandini G, Frasca F, Mineo R, Sciacca L, Vigneri R, Belfiore A. Insulin/insulin-like growth factor I hybrid receptors have different biological characteristics depending on the insulin receptor isoform involved. J Biol Chem 2002;277:39684-95.

38. Arcidiacono D, Dedja A, Giacometti C, Fassan M, Nucci D, Francia S, et al. Hyperinsulinemia promotes esophageal cancer development in a surgically-induced duodeno-esophageal reflux murine Model. Int J Mol Sci 2018;19:1198.

39. Belfiore A, Frasca F, Pandini G, Sciacca L, Vigneri R. Insulin receptor isoforms and insulin receptor/insulin-like growth factor receptor hybrids in physiology and disease. Endocr Rev 2009;30:586-623.

40. Belfiore A, Malaguarnera R, Vella V, Lawrence MC, Sciacca L, Frasca F, et al. Insulin receptor isoforms in physiology and disease: an updated view. Endocr Rev 2017;38:379-431.

41. Boucher J, Kleinridders A, Kahn CR. Insulin receptor signaling in normal and insulin-resistant states. Cold Spring Harb Perspect Biol 2014;6:a009191.

42. Haeusler RA, McGraw TE, Accili D. Biochemical and cellular properties of insulin receptor signalling. Nat Rev Mol Cell Biol 2018;19:31-44.

43. Trajkovic-Arsic M, Kalideris E, Siveke JT. The role of insulin and IGF system in pancreatic cancer. J Mol Endocrinol 2013; 50:R67-74.

44. Templeman NM, Flibotte S, Chik JH, Sinha S, Lim GE, Foster LJ, et al. Reduced circulating insulin enhances insulin sensitivity in old mice and extends lifespan. Cell Rep 2017;20:45163.

45. Ferguson RD, Gallagher EJ, Cohen D, Tobin-Hess A, Alikhani $\mathrm{N}$, Novosyadlyy R, et al. Hyperinsulinemia promotes metastasis to the lung in a mouse model of Her2-mediated breast cancer. Endocr Relat Cancer 2013;20:391-401.

46. Ferguson RD, Novosyadlyy R, Fierz Y, Alikhani N, Sun H, Yakar S, et al. Hyperinsulinemia enhances c-Myc-mediated mammary tumor development and advances metastatic progression to the lung in a mouse model of type 2 diabetes. Breast Cancer Res 2012;14:R8.

47. Novosyadlyy R, Lann DE, Vijayakumar A, Rowzee A, Lazzarino DA, Fierz Y, et al. Insulin-mediated acceleration of breast cancer development and progression in a nonobese model of type 2 diabetes. Cancer Res 2010;70:741-51.

48. Tatar M, Kopelman A, Epstein D, Tu MP, Yin CM, Garofalo RS. A mutant Drosophila insulin receptor homolog that extends life-span and impairs neuroendocrine function. Science 2001;292:107-10.

49. Clancy DJ, Gems D, Harshman LG, Oldham S, Stocker H, Hafen E, et al. Extension of life-span by loss of CHICO, a Drosophila insulin receptor substrate protein. Science 2001;292: 104-6.

50. Selman C, Lingard S, Choudhury AI, Batterham RL, Claret M, Clements $\mathrm{M}$, et al. Evidence for lifespan extension and delayed age-related biomarkers in insulin receptor substrate 1 null mice. FASEB J 2008;22:807-18.

51. Selman C, Partridge L, Withers DJ. Replication of extended lifespan phenotype in mice with deletion of insulin receptor substrate 1. PLoS One 2011;6:e16144.

52. Pawlikowska L, Hu D, Huntsman S, Sung A, Chu C, Chen J, et al. Association of common genetic variation in the insulin/ IGF1 signaling pathway with human longevity. Aging Cell 2009;8:460-72.

53. Bonafe M, Olivieri F. Genetic polymorphism in long-lived people: cues for the presence of an insulin/IGF-pathway-dependent network affecting human longevity. Mol Cell Endocrinol 2009;299:118-23. 
54. Holzenberger M, Dupont J, Ducos B, Leneuve P, Geloen A, Even PC, et al. IGF-1 receptor regulates lifespan and resistance to oxidative stress in mice. Nature 2003;421:182-7.

55. Bokov AF, Garg N, Ikeno Y, Thakur S, Musi N, DeFronzo RA, et al. Does reduced IGF-1R signaling in Igf1r+/- mice alter aging? PLoS One 2011;6:e26891.

56. Svensson J, Sjogren K, Faldt J, Andersson N, Isaksson O, Jansson JO, et al. Liver-derived IGF-I regulates mean life span in mice. PLoS One 2011;6:e22640.

57. Narasimhan SD, Yen K, Tissenbaum HA. Converging pathways in lifespan regulation. Curr Biol 2009;19:R657-66.

58. Bluher M, Kahn BB, Kahn CR. Extended longevity in mice lacking the insulin receptor in adipose tissue. Science 2003; 299:572-4.

59. Katic M, Kennedy AR, Leykin I, Norris A, McGettrick A, Gesta $S$, et al. Mitochondrial gene expression and increased oxidative metabolism: role in increased lifespan of fat-specific insulin receptor knock-out mice. Aging Cell 2007;6:827-39.

60. Katic M, Kahn CR. The role of insulin and IGF-1 signaling in longevity. Cell Mol Life Sci 2005;62:320-43.

61. Nakae J, Kido Y, Accili D. Distinct and overlapping functions of insulin and IGF-I receptors. Endocr Rev 2001;22:818-35.

62. Cohen E, Dillin A. The insulin paradox: aging, proteotoxicity and neurodegeneration. Nat Rev Neurosci 2008;9:759-67.

63. Wolff S, Dillin A. The trifecta of aging in Caenorhabditis elegans. Exp Gerontol 2006;41:894-903.

64. Miller RA, Harrison DE, Allison DB, Bogue M, Debarba L, Diaz V, et al. Canagliflozin extends life span in genetically heterogeneous male but not female mice. JCI Insight 2020;5: e140019.

65. Stefan N, Birkenfeld AL, Schulze MB, Ludwig DS. Obesity and impaired metabolic health in patients with COVID-19. Nat Rev Endocrinol 2020;16:341-2.

66. Muniangi-Muhitu H, Akalestou E, Salem V, Misra S, Oliver NS, Rutter GA. COVID-19 and diabetes: a complex bidirectional relationship. Front Endocrinol (Lausanne) 2020;11: 582936.

67. Polonsky KS, Given BD, Van Cauter E. Twenty-four-hour profiles and pulsatile patterns of insulin secretion in normal and obese subjects. J Clin Invest 1988;81:442-8.

68. McAuley KA, Williams SM, Mann JI, Walker RJ, LewisBarned NJ, Temple LA, et al. Diagnosing insulin resistance in the general population. Diabetes Care 2001;24:460-4.

69. Wang M, Li J, Lim GE, Johnson JD. Is dynamic autocrine insulin signaling possible?: a mathematical model predicts pico- molar concentrations of extracellular monomeric insulin within human pancreatic islets. PLoS One 2013;8:e64860.

70. Song SH, Kjems L, Ritzel R, McIntyre SM, Johnson ML, Veldhuis JD, et al. Pulsatile insulin secretion by human pancreatic islets. J Clin Endocrinol Metab 2002;87:213-21.

71. Ludwig DS, Ebbeling CB. The carbohydrate-insulin model of obesity: beyond "calories in, calories out". JAMA Intern Med 2018;178:1098-103.

72. Ludwig DS, Ebbeling CB, Bikman BT, Johnson JD. Testing the carbohydrate-insulin model in mice: the importance of distinguishing primary hyperinsulinemia from insulin resistance and metabolic dysfunction. Mol Metab 2020;35:100960.

73. Bergman RN, Piccinini F, Kabir M, Ader M. Novel aspects of the role of the liver in carbohydrate metabolism. Metabolism 2019;99:119-25.

74. Najjar SM, Perdomo G. Hepatic insulin clearance: mechanism and physiology. Physiology (Bethesda) 2019;34:198-215.

75. Bojsen-Moller KN, Lundsgaard AM, Madsbad S, Kiens B, Holst JJ. Hepatic insulin clearance in regulation of systemic insulin concentrations: role of carbohydrate and energy availability. Diabetes 2018;67:2129-36.

76. Tokarz VL, MacDonald PE, Klip A. The cell biology of systemic insulin function. J Cell Biol 2018;217:2273-89.

77. Shanik MH, Xu Y, Skrha J, Dankner R, Zick Y, Roth J. Insulin resistance and hyperinsulinemia: is hyperinsulinemia the cart or the horse? Diabetes Care 2008;31 Suppl 2:S262-8.

78. Dankner R, Chetrit A, Shanik MH, Raz I, Roth J. Basal state hyperinsulinemia in healthy normoglycemic adults heralds dysglycemia after more than two decades of follow up. Diabetes Metab Res Rev 2012;28:618-24.

79. Page MM, Johnson JD. Mild suppression of hyperinsulinemia to treat obesity and insulin resistance. Trends Endocrinol Metab 2018;29:389-99.

80. Lotta LA, Gulati P, Day FR, Payne F, Ongen H, van de Bunt M, et al. Integrative genomic analysis implicates limited peripheral adipose storage capacity in the pathogenesis of human insulin resistance. Nat Genet 2017;49:17-26.

81. Chawla S, Pund A, Vibishan B, Kulkarni S, Diwekar-Joshi M, Watve M. Inferring causal pathways among three or more variables from steady-state correlations in a homeostatic system. PLoS One 2018;13:e0204755.

82. Odeleye OE, de Courten M, Pettitt DJ, Ravussin E. Fasting hyperinsulinemia is a predictor of increased body weight gain and obesity in Pima Indian children. Diabetes 1997;46:13415. 
83. Le Stunff C, Bougneres P. Early changes in postprandial insulin secretion, not in insulin sensitivity, characterize juvenile obesity. Diabetes 1994;43:696-702.

84. Genuth SM, Przybylski RJ, Rosenberg DM. Insulin resistance in genetically obese, hyperglycemic mice. Endocrinology 1971;88:1230-8.

85. Grundleger ML, Godbole VY, Thenen SW. Age-dependent development of insulin resistance of soleus muscle in genetically obese (ob/ob) mice. Am J Physiol 1980;239:E363-71.

86. Coleman DL, Hummel KP. Hyperinsulinemia in pre-weaning diabetes (db) mice. Diabetologia 1974;10 Suppl:607-10.

87. Zarjevski N, Doyle P, Jeanrenaud B. Muscle insulin resistance may not be a primary etiological factor in the genetically obese fa/fa rat. Endocrinology 1992;130:1564-70.

88. Ishikawa M, Pruneda ML, Adams-Huet B, Raskin P. Obesityindependent hyperinsulinemia in nondiabetic first-degree relatives of individuals with type 2 diabetes. Diabetes 1998;47: 788-92.

89. Koopmans SJ, Ohman L, Haywood JR, Mandarino LJ, DeFronzo RA. Seven days of euglycemic hyperinsulinemia induces insulin resistance for glucose metabolism but not hypertension, elevated catecholamine levels, or increased sodium retention in conscious normal rats. Diabetes 1997;46: 1572-8.

90. Zimmet P, Dowse G, Bennett P. Hyperinsulinaemia is a predictor of non-insulin-dependent diabetes mellitus. Diabete Metab 1991;17(1 Pt 2):101-8.

91. Gray SL, Donald C, Jetha A, Covey SD, Kieffer TJ. Hyperinsulinemia precedes insulin resistance in mice lacking pancreatic beta-cell leptin signaling. Endocrinology 2010;151:4178-86.

92. Thomas DD, Corkey BE, Istfan NW, Apovian CM. Hyperinsulinemia: an early indicator of metabolic dysfunction. J Endocr Soc 2019;3:1727-47.

93. Trico D, Natali A, Arslanian S, Mari A, Ferrannini E. Identification, pathophysiology, and clinical implications of primary insulin hypersecretion in nondiabetic adults and adolescents. JCI Insight 2018;3:e124912.

94. van Vliet S, Koh HE, Patterson BW, Yoshino M, LaForest R, Gropler RJ, et al. Obesity is associated with increased basal and postprandial $\beta$-cell insulin secretion even in the absence of insulin resistance. Diabetes 2020;69:2112-9.

95. Gregory JM, Cherrington AD, Moore DJ. The peripheral peril: injected insulin induces insulin insensitivity in type 1 diabetes. Diabetes 2020;69:837-47.

96. Yeo GSH. Genetics of obesity: can an old dog teach us new tricks? Diabetologia 2017;60:778-83.

97. Do R, Bailey SD, Desbiens K, Belisle A, Montpetit A, Bouchard C, et al. Genetic variants of FTO influence adiposity, insulin sensitivity, leptin levels, and resting metabolic rate in the Quebec Family Study. Diabetes 2008;57:1147-50.

98. Astley CM, Todd JN, Salem RM, Vedantam S, Ebbeling CB, Huang PL, et al. Genetic evidence that carbohydrate-stimulated insulin secretion leads to obesity. Clin Chem 2018;64:192200.

99. Xu H, Jin C, Guan Q. Causal effects of overall and abdominal obesity on insulin resistance and the risk of type 2 diabetes mellitus: a two-sample mendelian randomization study. Front Genet 2020;11:603.

100. Pal A, Barber TM, Van de Bunt M, Rudge SA, Zhang Q, Lachlan KL, et al. PTEN mutations as a cause of constitutive insulin sensitivity and obesity. N Engl J Med 2012;367:1002-11.

101. Adam MP, Ardinger HH, Pagon RA, Wallace SE, Bean LJH, Stephens K, et al. GeneReviews. Seattle: University of Washington Seattle; 1993. Chapter, INSR-related severe syndromic insulin resistance. https://www.ncbi.nlm.nih.gov/books/ NBK476444.

102. Corkey BE. Banting lecture 2011: hyperinsulinemia: cause or consequence? Diabetes 2012;61:4-13.

103. Sutton EF, Beyl R, Early KS, Cefalu WT, Ravussin E, Peterson CM. Early time-restricted feeding improves insulin sensitivity, blood pressure, and oxidative stress even without weight loss in men with prediabetes. Cell Metab 2018;27:1212-21.

104. Lean ME, Leslie WS, Barnes AC, Brosnahan N, Thom G, McCombie L, et al. Primary care-led weight management for remission of type 2 diabetes (DiRECT): an open-label, clusterrandomised trial. Lancet 2018;391:541-51.

105. Taylor R, Al-Mrabeh A, Zhyzhneuskaya S, Peters C, Barnes AC, Aribisala BS, et al. Remission of human type 2 diabetes requires decrease in liver and pancreas fat content but is dependent upon capacity for $\beta$ cell recovery. Cell Metab 2018;28: 547-56.

106. Hallberg SJ, McKenzie AL, Williams PT, Bhanpuri NH, Peters AL, Campbell WW, et al. Effectiveness and safety of a novel care model for the management of type 2 diabetes at 1 year: an open-label, non-randomized, controlled study. Diabetes Ther 2018;9:583-612.

107. Alemzadeh R, Langley G, Upchurch L, Smith P, Slonim AE. Beneficial effect of diazoxide in obese hyperinsulinemic adults. J Clin Endocrinol Metab 1998;83:1911-5.

108. Lustig RH, Hinds PS, Ringwald-Smith K, Christensen RK, 
Kaste SC, Schreiber RE, et al. Octreotide therapy of pediatric hypothalamic obesity: a double-blind, placebo-controlled trial. J Clin Endocrinol Metab 2003;88:2586-92.

109. Loves S, van Groningen L, Filius M, Mekking M, Brandon T, Tack CJ, et al. Effects of diazoxide-mediated insulin suppression on glucose and lipid metabolism in nondiabetic obese men. J Clin Endocrinol Metab 2018;103:2346-53.

110. Alemzadeh R, Jacobs W, Pitukcheewanont P. Antiobesity effect of diazoxide in obese Zucker rats. Metabolism 1996;45: 334-41.

111. Lustig RH, Greenway F, Velasquez-Mieyer P, Heimburger D, Schumacher D, Smith D, et al. A multicenter, randomized, double-blind, placebo-controlled, dose-finding trial of a longacting formulation of octreotide in promoting weight loss in obese adults with insulin hypersecretion. Int J Obes (Lond) 2006;30:331-41.

112. Greenwood RH, Mahler RF, Hales CN. Improvement in insulin secretion in diabetes after diazoxide. Lancet 1976;1:444-7.

113. ORIGIN Trial Investigators, Gerstein HC, Bosch J, Dagenais GR, Diaz R, Jung H, et al. Basal insulin and cardiovascular and other outcomes in dysglycemia. N Engl J Med 2012;367: 319-28.

114. Botezelli JD, Overby P, Lindo L, Wang S, Haida O, Lim GE, et al. Adipose depot-specific upregulation of Ucp1 or mitochondrial oxidative complex proteins are early consequences of genetic insulin reduction in mice. Am J Physiol Endocrinol Metab 2020;319:E529-39.

115. Templeman NM, Mehran AE, Johnson JD. Hyper-variability in circulating insulin, high fat feeding outcomes, and effects of reducing Ins2 dosage in male Ins1-null mice in a specific pathogen-free facility. PLoS One 2016;11:e0153280.

116. D’souza AM, Johnson JD, Clee SM, Kieffer TJ. Suppressing hyperinsulinemia prevents obesity but causes rapid onset of diabetes in leptin-deficient Lepob/ob mice. Mol Metab 2016; 5:1103-12.

117. Page MM, Skovso S, Cen H, Chiu AP, Dionne DA, Hutchinson DF, et al. Reducing insulin via conditional partial gene ablation in adults reverses diet-induced weight gain. FASEB J 2018;32:1196-206.

118. Vetterli L, Carobbio S, Frigerio F, Karaca M, Maechler P. The amplifying pathway of the $\beta$-cell contributes to diet-induced obesity. J Biol Chem 2016;291:13063-75.

119. Erion KA, Corkey BE. Hyperinsulinemia: a cause of obesity? Curr Obes Rep 2017;6:178-86.

120. Softic S, Boucher J, Solheim MH, Fujisaka S, Haering MF,
Homan EP, et al. Lipodystrophy due to adipose tissue-specific insulin receptor knockout results in progressive NAFLD. Diabetes 2016;65:2187-200.

121. Stumvoll M, Jacob S, Wahl HG, Hauer B, Loblein K, Grauer P, et al. Suppression of systemic, intramuscular, and subcutaneous adipose tissue lipolysis by insulin in humans. J Clin Endocrinol Metab 2000;85:3740-5.

122. Czech MP, Tencerova M, Pedersen DJ, Aouadi M. Insulin signalling mechanisms for triacylglycerol storage. Diabetologia 2013;56:949-64.

123. Kersten S. Mechanisms of nutritional and hormonal regulation of lipogenesis. EMBO Rep 2001;2:282-6.

124. Lee SH, Zabolotny JM, Huang H, Lee H, Kim YB. Insulin in the nervous system and the mind: functions in metabolism, memory, and mood. Mol Metab 2016;5:589-601.

125. Scherer T, O’Hare J, Diggs-Andrews K, Schweiger M, Cheng B, Lindtner C, et al. Brain insulin controls adipose tissue lipolysis and lipogenesis. Cell Metab 2011;13:183-94.

126. Stockhorst U, de Fries D, Steingrueber HJ, Scherbaum WA. Insulin and the CNS: effects on food intake, memory, and endocrine parameters and the role of intranasal insulin administration in humans. Physiol Behav 2004;83:47-54.

127. Figlewicz DP. Adiposity signals and food reward: expanding the CNS roles of insulin and leptin. Am J Physiol Regul Integr Comp Physiol 2003;284:R882-92.

128. Porte D Jr, Baskin DG, Schwartz MW. Leptin and insulin action in the central nervous system. Nutr Rev 2002;60(10 Pt 2): S20-9,S68-87.

129. Brief DJ, Davis JD. Reduction of food intake and body weight by chronic intraventricular insulin infusion. Brain Res Bull 1984;12:571-5.

130. Koch L, Wunderlich FT, Seibler J, Konner AC, Hampel B, Irlenbusch S, et al. Central insulin action regulates peripheral glucose and fat metabolism in mice. J Clin Invest 2008;118: 2132-47.

131. Obici S, Feng Z, Karkanias G, Baskin DG, Rossetti L. Decreasing hypothalamic insulin receptors causes hyperphagia and insulin resistance in rats. Nat Neurosci 2002;5:566-72.

132. Bruning JC, Gautam D, Burks DJ, Gillette J, Schubert M, Orban PC, et al. Role of brain insulin receptor in control of body weight and reproduction. Science 2000;289:2122-5.

133. Petrick HL, Foley KP, Zlitni S, Brunetta HS, Paglialunga S, Miotto PM, et al. Adipose tissue inflammation is directly linked to obesity-induced insulin resistance, while gut dysbiosis and mitochondrial dysfunction are not required. Function 
2020;1:zqaa013.

134. Johnson AM, Olefsky JM. The origins and drivers of insulin resistance. Cell 2013;152:673-84.

135. DeFronzo RA, Ferrannini E, Groop L, Henry RR, Herman WH, Holst JJ, et al. Type 2 diabetes mellitus. Nat Rev Dis Primers 2015;1:15019.

136. Orliaguet L, Dalmas E, Drareni K, Venteclef N, Alzaid F. Mechanisms of macrophage polarization in insulin signaling and sensitivity. Front Endocrinol (Lausanne) 2020;11:62.

137. Shimobayashi M, Albert V, Woelnerhanssen B, Frei IC, Weissenberger D, Meyer-Gerspach AC, et al. Insulin resistance causes inflammation in adipose tissue. J Clin Invest 2018;128: 1538-50.

138. Bruin JE, Saber N, Braun N, Fox JK, Mojibian M, Asadi A, et al. Treating diet-induced diabetes and obesity with human embryonic stem cell-derived pancreatic progenitor cells and antidiabetic drugs. Stem Cell Reports 2015;4:605-20.

139. Pedersen DJ, Guilherme A, Danai LV, Heyda L, Matevossian A, Cohen J, et al. A major role of insulin in promoting obesity-associated adipose tissue inflammation. Mol Metab 2015;4: 507-18.

140. Krogh-Madsen R, Plomgaard P, Keller P, Keller C, Pedersen BK. Insulin stimulates interleukin-6 and tumor necrosis factor-alpha gene expression in human subcutaneous adipose tissue. Am J Physiol Endocrinol Metab 2004;286:E234-8.

141. Soop M, Duxbury H, Agwunobi AO, Gibson JM, Hopkins SJ, Childs $\mathrm{C}$, et al. Euglycemic hyperinsulinemia augments the cytokine and endocrine responses to endotoxin in humans. Am J Physiol Endocrinol Metab 2002;282:E1276-85.

142. Westerbacka J, Corner A, Kannisto K, Kolak M, Makkonen J, Korsheninnikova E, et al. Acute in vivo effects of insulin on gene expression in adipose tissue in insulin-resistant and insulin-sensitive subjects. Diabetologia 2006;49:132-40.

143. Westerbacka J, Corner A, Kolak M, Makkonen J, Turpeinen U, Hamsten A, et al. Insulin regulation of MCP-1 in human adipose tissue of obese and lean women. Am J Physiol Endocrinol Metab 2008;294:E841-5.

144. Beaton GH, Curry DM. A comparison of the effects of hormone and of insulin administration. Endocrinology 1956;58: 797-801.

145. Renold AE, Marble A, Fawcett DW. Action of insulin on deposition of glycogen and storage of fat in adipose tissue. Endocrinology 1950;46:55-66.

146. Bornstein SR, Abu-Asab M, Glasow A, Path G, Hauner H, Tsokos $\mathrm{M}$, et al. Immunohistochemical and ultrastructural localization of leptin and leptin receptor in human white adipose tissue and differentiating human adipose cells in primary culture. Diabetes 2000;49:532-8.

147. Surmi BK, Hasty AH. Macrophage infiltration into adipose tissue: initiation, propagation and remodeling. Future Lipidol 2008;3:545-56.

148. Weisberg SP, McCann D, Desai M, Rosenbaum M, Leibel RL, Ferrante AW Jr. Obesity is associated with macrophage accumulation in adipose tissue. J Clin Invest 2003;112:1796-808.

149. Xu H, Barnes GT, Yang Q, Tan G, Yang D, Chou CJ, et al. Chronic inflammation in fat plays a crucial role in the development of obesity-related insulin resistance. J Clin Invest 2003;112:1821-30.

150. Stentz FB, Kitabchi AE. De novo emergence of growth factor receptors in activated human CD4+ and CD8+ T lymphocytes. Metabolism 2004;53:117-22.

151. Tsai S, Clemente-Casares X, Zhou AC, Lei H, Ahn JJ, Chan YT, et al. Insulin receptor-mediated stimulation boosts $\mathrm{T}$ cell immunity during inflammation and infection. Cell Metab 2018;28:922-34.

152. Viardot A, Grey ST, Mackay F, Chisholm D. Potential antiinflammatory role of insulin via the preferential polarization of effector T cells toward a T helper 2 phenotype. Endocrinology 2007;148:346-53.

153. Han JM, Patterson SJ, Speck M, Ehses JA, Levings MK. Insulin inhibits IL-10-mediated regulatory T cell function: implications for obesity. J Immunol 2014;192:623-9.

154. Fischer HJ, Sie C, Schumann E, Witte AK, Dressel R, van den Brandt J, et al. The insulin receptor plays a critical role in $\mathrm{T}$ cell function and adaptive immunity. J Immunol 2017;198: 1910-20.

155. Han JM, Patterson SJ, Levings MK. The role of the PI3K signaling pathway in CD4(+) T cell differentiation and function. Front Immunol 2012;3:245.

156. Carbo R, Guarner V. Insulin effect on glucose transport in thymocytes and splenocytes from rats with metabolic syndrome. Diabetol Metab Syndr 2010;2:64.

157. Wang R, Dillon CP, Shi LZ, Milasta S, Carter R, Finkelstein D, et al. The transcription factor Myc controls metabolic reprogramming upon T lymphocyte activation. Immunity 2011;35: 871-82.

158. Maratou E, Dimitriadis G, Kollias A, Boutati E, Lambadiari V, Mitrou P, et al. Glucose transporter expression on the plasma membrane of resting and activated white blood cells. Eur J Clin Invest 2007;37:282-90. 
159. Feuerer M, Herrero L, Cipolletta D, Naaz A, Wong J, Nayer A, et al. Lean, but not obese, fat is enriched for a unique population of regulatory $\mathrm{T}$ cells that affect metabolic parameters. Nat Med 2009;15:930-9.

160. Winer S, Chan Y, Paltser G, Truong D, Tsui H, Bahrami J, et al. Normalization of obesity-associated insulin resistance through immunotherapy. Nat Med 2009;15:921-9.

161. Patton DT, Garden OA, Pearce WP, Clough LE, Monk CR, Leung E, et al. Cutting edge: the phosphoinositide 3-kinase p110 delta is critical for the function of CD4+CD25+Foxp3+ regulatory T cells. J Immunol 2006;177:6598-602.

162. Patton DT, Wilson MD, Rowan WC, Soond DR, Okkenhaug $\mathrm{K}$. The PI3K p1108 regulates expression of CD38 on regulatory T cells. PLoS One 2011;6:e17359.

163. Ley K. M1 means kill: M2 means heal. J Immunol 2017;199: 2191-3.

164. Mills CD, Kincaid K, Alt JM, Heilman MJ, Hill AM. M-1/M-2 macrophages and the Th1/Th2 paradigm. J Immunol 2000; 164:6166-73.

165. Denroche HC, Nackiewicz D, Verchere CB. When beta cells talk back. Diabetologia 2018;61:39-42.

166. Kazankov K, Jorgensen SM, Thomsen KL, Moller HJ, Vilstrup $\mathrm{H}$, George J, et al. The role of macrophages in nonalcoholic fatty liver disease and nonalcoholic steatohepatitis. Nat Rev Gastroenterol Hepatol 2019;16:145-59.

167. Lackey DE, Olefsky JM. Regulation of metabolism by the innate immune system. Nat Rev Endocrinol 2016;12:15-28.

168. McNelis JC, Olefsky JM. Macrophages, immunity, and metabolic disease. Immunity 2014;41:36-48.

169. Glass CK, Olefsky JM. Inflammation and lipid signaling in the etiology of insulin resistance. Cell Metab 2012;15:635-45.

170. Ieronymaki E, Theodorakis EM, Lyroni K, Vergadi E, Lagoudaki E, Al-Qahtani A, et al. Insulin resistance in macrophages alters their metabolism and promotes an M2-like phenotype. J Immunol 2019;202:1786-97.

171. Senokuchi T, Liang CP, Seimon TA, Han S, Matsumoto M, Banks AS, et al. Forkhead transcription factors (FoxOs) promote apoptosis of insulin-resistant macrophages during cholesterol-induced endoplasmic reticulum stress. Diabetes 2008; 57:2967-76.

172. Arranz A, Doxaki C, Vergadi E, Martinez de la Torre Y, Vaporidi $\mathrm{K}$, Lagoudaki $\mathrm{ED}$, et al. Akt1 and Akt2 protein kinases differentially contribute to macrophage polarization. Proc Natl Acad Sci U S A 2012;109:9517-22.

173. Vergadi E, Vaporidi K, Theodorakis EE, Doxaki C, Lagoudaki
E, Ieronymaki E, et al. Akt2 deficiency protects from acute lung injury via alternative macrophage activation and miR146a induction in mice. J Immunol 2014;192:394-406.

174. Covarrubias AJ, Aksoylar HI, Horng T. Control of macrophage metabolism and activation by mTOR and Akt signaling. Semin Immunol 2015;27:286-96.

175. Byles V, Covarrubias AJ, Ben-Sahra I, Lamming DW, Sabatini DM, Manning BD, et al. The TSC-mTOR pathway regulates macrophage polarization. Nat Commun 2013;4:2834.

176. Luyendyk JP, Schabbauer GA, Tencati M, Holscher T, Pawlinski R, Mackman N. Genetic analysis of the role of the PI3KAkt pathway in lipopolysaccharide-induced cytokine and tissue factor gene expression in monocytes/macrophages. J Immunol 2008;180:4218-26.

177. Diaz-Guerra M), Castrillo A, Martin-Sanz P, Bosca L. Negative regulation by phosphatidylinositol 3-kinase of inducible nitric oxide synthase expression in macrophages. J Immunol 1999;162:6184-90.

178. Sahin E, Haubenwallner S, Kuttke M, Kollmann I, Halfmann A, Dohnal AM, et al. Macrophage PTEN regulates expression and secretion of arginase I modulating innate and adaptive immune responses. J Immunol 2014;193:1717-27.

179. Sly LM, Ho V, Antignano F, Ruschmann J, Hamilton M, Lam $\mathrm{V}$, et al. The role of SHIP in macrophages. Front Biosci 2007; 12:2836-48.

180. Weichhart T, Saemann MD. The multiple facets of mTOR in immunity. Trends Immunol 2009;30:218-26.

181. Johnson JD, Bernal-Mizrachi E, Alejandro EU, Han Z, Kalynyak TB, Li H, et al. Insulin protects islets from apoptosis via $\mathrm{Pdx} 1$ and specific changes in the human islet proteome. Proc Natl Acad Sci U S A 2006;103:19575-80.

182. Currie CJ, Poole CD, Gale EA. The influence of glucose-lowering therapies on cancer risk in type 2 diabetes. Diabetologia 2009;52:1766-77.

183. Colhoun HM; SDRN Epidemiology Group. Use of insulin glargine and cancer incidence in Scotland: a study from the Scottish Diabetes Research Network Epidemiology Group. Diabetologia 2009;52:1755-65.

184. Jonasson JM, Ljung R, Talback M, Haglund B, Gudbjornsdottir S, Steineck G. Insulin glargine use and short-term incidence of malignancies: a population-based follow-up study in Sweden. Diabetologia 2009;52:1745-54.

185. Hemkens LG, Grouven U, Bender R, Gunster C, Gutschmidt $\mathrm{S}$, Selke GW, et al. Risk of malignancies in patients with diabetes treated with human insulin or insulin analogues: a cohort 
study. Diabetologia 2009;52:1732-44.

186. Karlstad O, Starup-Linde J, Vestergaard P, Hjellvik V, Bazelier MT, Schmidt MK, et al. Use of insulin and insulin analogs and risk of cancer: systematic review and meta-analysis of observational studies. Curr Drug Saf 2013;8:333-48.

187. Wu JW, Azoulay L, Majdan A, Boivin JF, Pollak M, Suissa S. Long-term use of long-acting insulin analogs and breast cancer incidence in women with type 2 diabetes. J Clin Oncol 2017;35:3647-53.

188. Home P. Insulin therapy and cancer. Diabetes Care 2013;36 Suppl 2:S240-4.

189. Sciacca L, Vella V, Frittitta L, Tumminia A, Manzella L, Squatrito $\mathrm{S}$, et al. Long-acting insulin analogs and cancer. Nutr Metab Cardiovasc Dis 2018;28:436-43.

190. Badrick E, Renehan AG. Diabetes and cancer: 5 years into the recent controversy. Eur J Cancer 2014;50:2119-25.

191. Ioacara S, Guja C, Ionescu-Tirgoviste C, Fica S, Roden M. Cancer specific mortality in insulin-treated type 2 diabetes patients. PLoS One 2014;9:e93132.

192. Finlayson CA, Chappell J, Leitner JW, Goalstone ML, Garrity M, Nawaz S, et al. Enhanced insulin signaling via Shc in human breast cancer. Metabolism 2003;52:1606-11.

193. Boyd DB. Insulin and cancer. Integr Cancer Ther 2003;2:31529.

194. Kaaks R, Lukanova A. Energy balance and cancer: the role of insulin and insulin-like growth factor-I. Proc Nutr Soc 2001; 60:91-106.

195. Becker S, Dossus L, Kaaks R. Obesity related hyperinsulinaemia and hyperglycaemia and cancer development. Arch Physiol Biochem 2009;115:86-96.

196. Ma J, Giovannucci E, Pollak M, Leavitt A, Tao Y, Gaziano JM, et al. A prospective study of plasma C-peptide and colorectal cancer risk in men. J Natl Cancer Inst 2004;96:546-53.

197. Gunter MJ, Xie X, Xue X, Kabat GC, Rohan TE, WassertheilSmoller S, et al. Breast cancer risk in metabolically healthy but overweight postmenopausal women. Cancer Res 2015;75: 270-4.

198. Loftfield E, Freedman ND, Lai GY, Weinstein SJ, McGlynn KA, Taylor PR, et al. Higher glucose and insulin levels are associated with risk of liver cancer and chronic liver disease mortality among men without a history of diabetes. Cancer Prev Res (Phila) 2016;9:866-74.

199. Calle EE, Thun MJ, Petrelli JM, Rodriguez C, Heath CW Jr. Body-mass index and mortality in a prospective cohort of U.S. adults. N Engl J Med 1999;341:1097-105.
200. Campbell PT, Newton CC, Patel AV, Jacobs EJ, Gapstur SM. Diabetes and cause-specific mortality in a prospective cohort of one million U.S. adults. Diabetes Care 2012;35:1835-44.

201. Pearson-Stuttard J, Zhou B, Kontis V, Bentham J, Gunter MJ, Ezzati M. Worldwide burden of cancer attributable to diabetes and high body-mass index: a comparative risk assessment. Lancet Diabetes Endocrinol 2018;6:e6-15.

202. Zhou XH, Qiao Q, Zethelius B, Pyorala K, Soderberg S, Pajak A, et al. Diabetes, prediabetes and cancer mortality. Diabetologia 2010;53:1867-76.

203. Chan DSM, Vieira AR, Aune D, Bandera EV, Greenwood DC, McTiernan A, et al. Body mass index and survival in women with breast cancer-systematic literature review and metaanalysis of 82 follow-up studies. Ann Oncol 2014;25:1901-14.

204. Doleman B, Mills KT, Lim S, Zelhart MD, Gagliardi G. Body mass index and colorectal cancer prognosis: a systematic review and meta-analysis. Tech Coloproctol 2016;20:517-35.

205. Morales Camacho WJ, Molina Diaz JM, Plata Ortiz S, Plata Ortiz JE, Morales Camacho MA, Calderon BP. Childhood obesity: aetiology, comorbidities, and treatment. Diabetes Metab Res Rev 2019;35:e3203.

206. Mitchell NS, Catenacci VA, Wyatt HR, Hill JO. Obesity: overview of an epidemic. Psychiatr Clin North Am 2011;34:717-32.

207. Hruby A, Hu FB. The epidemiology of obesity: a big picture. Pharmacoeconomics 2015;33:673-89.

208. Rowley WR, Bezold C, Arikan Y, Byrne E, Krohe S. Diabetes 2030: insights from yesterday, today, and future trends. Popul Health Manag 2017;20:6-12.

209. Gallagher EJ, LeRoith D. Obesity and diabetes: the increased risk of cancer and cancer-related mortality. Physiol Rev 2015; 95:727-48.

210. Parekh N, Chandran U, Bandera EV. Obesity in cancer survival. Annu Rev Nutr 2012;32:311-42.

211. Godsland IF. Insulin resistance and hyperinsulinaemia in the development and progression of cancer. Clin Sci (Lond) 2009; 118:315-32.

212. Arcidiacono B, Iiritano S, Nocera A, Possidente K, Nevolo MT, Ventura $V$, et al. Insulin resistance and cancer risk: an overview of the pathogenetic mechanisms. Exp Diabetes Res 2012;2012:789174.

213. Perseghin G, Calori G, Lattuada G, Ragogna F, Dugnani E, Garancini MP, et al. Insulin resistance/hyperinsulinemia and cancer mortality: the Cremona study at the 15th year of follow-up. Acta Diabetol 2012;49:421-8.

214. Tsujimoto T, Kajio H, Sugiyama T. Association between hy- 
perinsulinemia and increased risk of cancer death in nonobese and obese people: a population-based observational study. Int J Cancer 2017;141:102-11.

215. Fisher WE, Boros LG, Schirmer WJ. Insulin promotes pancreatic cancer: evidence for endocrine influence on exocrine pancreatic tumors. J Surg Res 1996;63:310-3.

216. Pisani P. Hyper-insulinaemia and cancer, meta-analyses of epidemiological studies. Arch Physiol Biochem 2008;114:63-70.

217. Dugnani E, Balzano G, Pasquale V, Scavini M, Aleotti F, Liberati $\mathrm{D}$, et al. Insulin resistance is associated with the aggressiveness of pancreatic ductal carcinoma. Acta Diabetol 2016; 53:945-56.

218. Michaud DS, Wolpin B, Giovannucci E, Liu S, Cochrane B, Manson JE, et al. Prediagnostic plasma C-peptide and pancreatic cancer risk in men and women. Cancer Epidemiol Biomarkers Prev 2007;16:2101-9.

219. Stolzenberg-Solomon RZ, Graubard BI, Chari S, Limburg P, Taylor PR, Virtamo J, et al. Insulin, glucose, insulin resistance, and pancreatic cancer in male smokers. JAMA 2005;294: 2872-8.

220. Hirose K, Toyama T, Iwata H, Takezaki T, Hamajima N, Tajima K. Insulin, insulin-like growth factor-I and breast cancer risk in Japanese women. Asian Pac J Cancer Prev 2003;4:23946.

221. Lawlor DA, Smith GD, Ebrahim S. Hyperinsulinaemia and increased risk of breast cancer: findings from the British Women's Heart and Health Study. Cancer Causes Control 2004;15:267-75.

222. Kabat GC, Kim M, Caan BJ, Chlebowski RT, Gunter MJ, Ho GY, et al. Repeated measures of serum glucose and insulin in relation to postmenopausal breast cancer. Int J Cancer 2009; 125:2704-10.

223. Yang G, Lu G, Jin F, Dai Q, Best R, Shu XO, et al. Populationbased, case-control study of blood C-peptide level and breast cancer risk. Cancer Epidemiol Biomarkers Prev 2001;10: 1207-11.

224. Limburg PJ, Stolzenberg-Solomon RZ, Vierkant RA, Roberts $\mathrm{K}$, Sellers TA, Taylor PR, et al. Insulin, glucose, insulin resistance, and incident colorectal cancer in male smokers. Clin Gastroenterol Hepatol 2006;4:1514-21.

225. Kaaks R, Toniolo P, Akhmedkhanov A, Lukanova A, Biessy C, Dechaud H, et al. Serum C-peptide, insulin-like growth factor (IGF)-I, IGF-binding proteins, and colorectal cancer risk in women. J Natl Cancer Inst 2000;92:1592-600.

226. Hammarsten J, Hogstedt B. Hyperinsulinaemia: a prospective risk factor for lethal clinical prostate cancer. Eur J Cancer 2005;41:2887-95.

227. Cust AE, Allen NE, Rinaldi S, Dossus L, Friedenreich C, Olsen A, et al. Serum levels of C-peptide, IGFBP-1 and IGFBP-2 and endometrial cancer risk: results from the European prospective investigation into cancer and nutrition. Int J Cancer 2007;120:2656-64.

228. Gunter MJ, Hoover DR, Yu H, Wassertheil-Smoller S, Manson JE, Li J, et al. A prospective evaluation of insulin and insulin-like growth factor-I as risk factors for endometrial cancer. Cancer Epidemiol Biomarkers Prev 2008;17:921-9.

229. Sun W, Lu J, Wu S, Bi Y, Mu Y, Zhao J, et al. Association of insulin resistance with breast, ovarian, endometrial and cervical cancers in non-diabetic women. Am J Cancer Res 2016;6: 2334-2344.

230. Walraven I, van 't Riet E, Stehouwer CD, Polak BC, Moll AC, Dekker JM, et al. Fasting proinsulin levels are significantly associated with 20 year cancer mortality rates: the Hoorn Study. Diabetologia 2013;56:1148-54.

231. Colangelo LA, Gapstur SM, Gann PH, Dyer AR, Liu K. Colorectal cancer mortality and factors related to the insulin resistance syndrome. Cancer Epidemiol Biomarkers Prev 2002;11:385-91.

232. Milazzo G, Giorgino F, Damante G, Sung C, Stampfer MR, Vigneri $\mathrm{R}$, et al. Insulin receptor expression and function in human breast cancer cell lines. Cancer Res 1992;52:3924-30.

233. Papa V, Pezzino V, Costantino A, Belfiore A, Giuffrida D, Frittitta L, et al. Elevated insulin receptor content in human breast cancer. J Clin Invest 1990;86:1503-10.

234. Mulligan AM, O’Malley FP, Ennis M, Fantus IG, Goodwin PJ. Insulin receptor is an independent predictor of a favorable outcome in early stage breast cancer. Breast Cancer Res Treat 2007;106:39-47.

235. Aljada A, Saleh AM, Al-Aqeel SM, Shamsa HB, Al-Bawab A, Al Dubayee M, et al. Quantification of insulin receptor mRNA splice variants as a diagnostic tumor marker in breast cancer. Cancer Biomark 2015;15:653-61.

236. Harrington SC, Weroha SJ, Reynolds C, Suman VJ, Lingle WL, Haluska P. Quantifying insulin receptor isoform expression in FFPE breast tumors. Growth Horm IGF Res 2012;22: 108-15.

237. Heni M, Hennenlotter J, Scharpf M, Lutz SZ, Schwentner C, Todenhofer $\mathrm{T}$, et al. Insulin receptor isoforms $\mathrm{A}$ and $\mathrm{B}$ as well as insulin receptor substrates- 1 and -2 are differentially expressed in prostate cancer. PLoS One 2012;7:e50953. 
238. Perks CM, Zielinska HA, Wang J, Jarrett C, Frankow A, Ladomery MR, et al. Insulin receptor isoform variations in prostate cancer cells. Front Endocrinol (Lausanne) 2016;7:132.

239. Cox ME, Gleave ME, Zakikhani M, Bell RH, Piura E, Vickers $\mathrm{E}$, et al. Insulin receptor expression by human prostate cancers. Prostate 2009;69:33-40.

240. Wang CF, Zhang G, Zhao LJ, Qi WJ, Li XP, Wang JL, et al. Overexpression of the insulin receptor isoform A promotes endometrial carcinoma cell growth. PLoS One 2013;8:e69001.

241. Flannery CA, Saleh FL, Choe GH, Selen DJ, Kodaman PH, Kliman HJ, et al. Differential expression of IR-A, IR-B and IGF-1R in endometrial physiology and distinct signature in adenocarcinoma. J Clin Endocrinol Metab 2016;101:2883-91.

242. Forest A, Amatulli M, Ludwig DL, Damoci CB, Wang Y, Burns CA, et al. Intrinsic resistance to cixutumumab is conferred by distinct isoforms of the insulin receptor. Mol Cancer Res 2015;13:1615-26.

243. Jiang L, Zhu W, Streicher K, Morehouse C, Brohawn P, Ge X, et al. Increased IR-A/IR-B ratio in non-small cell lung cancers associates with lower epithelial-mesenchymal transition signature and longer survival in squamous cell lung carcinoma. BMC Cancer 2014;14:131.

244. Sen S, Langiewicz M, Jumaa H, Webster NJ. Deletion of serine/arginine-rich splicing factor 3 in hepatocytes predisposes to hepatocellular carcinoma in mice. Hepatology 2015;61: 171-83.

245. Jiang W, Jin Z, Zhou F, Cui J, Wang L, Wang L. High co-expression of Sp1 and HER-2 is correlated with poor prognosis of gastric cancer patients. Surg Oncol 2015;24:220-5.

246. Wang J, Kang M, Qin YT, Wei ZX, Xiao JJ, Wang RS. Sp1 is over-expressed in nasopharyngeal cancer and is a poor prognostic indicator for patients receiving radiotherapy. Int J Clin Exp Pathol 2015;8:6936-43.

247. Sumter TF, Xian L, Huso T, Koo M, Chang YT, Almasri TN, et al. The high mobility group A1 (HMGA1) transcriptome in cancer and development. Curr Mol Med 2016;16:353-93.

248. Foti D, Iuliano R, Chiefari E, Brunetti A. A nucleoprotein complex containing Sp1, C/EBP beta, and HMGI-Y controls human insulin receptor gene transcription. Mol Cell Biol 2003; 23:2720-32.

249. Webster NJ, Resnik JL, Reichart DB, Strauss B, Haas M, Seely $\mathrm{BL}$. Repression of the insulin receptor promoter by the tumor suppressor gene product p53: a possible mechanism for receptor overexpression in breast cancer. Cancer Res 1996;56: 2781-8.
250. Lovat F, Fassan M, Gasparini P, Rizzotto L, Cascione L, Pizzi $\mathrm{M}$, et al. miR-15b/16-2 deletion promotes B-cell malignancies. Proc Natl Acad Sci U S A 2015;112:11636-41.

251. Marchand A, Atassi F, Mougenot N, Clergue M, Codoni V, Berthuin J, et al. miR-322 regulates insulin signaling pathway and protects against metabolic syndrome-induced cardiac dysfunction in mice. Biochim Biophys Acta 2016;1862:61121.

252. Kaminska D, Hamalainen M, Cederberg H, Kakela P, Venesmaa S, Miettinen P, et al. Adipose tissue INSR splicing in humans associates with fasting insulin level and is regulated by weight loss. Diabetologia 2014;57:347-51.

253. Besic V, Shi H, Stubbs RS, Hayes MT. Aberrant liver insulin receptor isoform a expression normalises with remission of type 2 diabetes after gastric bypass surgery. PLoS One 2015; 10:e0119270.

254. Saeki K, Yasugi E, Okuma E, Breit SN, Nakamura M, Toda T, et al. Proteomic analysis on insulin signaling in human hematopoietic cells: identification of CLIC1 and SRp20 as novel downstream effectors of insulin. Am J Physiol Endocrinol Metab 2005;289:E419-28.

255. Rostoker R, Bitton-Worms K, Caspi A, Shen-Orr Z, LeRoith D. Investigating new therapeutic strategies targeting hyperinsulinemia's mitogenic effects in a female mouse breast cancer model. Endocrinology 2013;154:1701-10.

256. Manning BD, Cantley LC. AKT/PKB signaling: navigating downstream. Cell 2007;129:1261-74.

257. Cheng X, Xia W, Yang JY, Hsu JL, Lang JY, Chou CK, et al. Activation of murine double minute 2 by Akt in mammary epithelium delays mammary involution and accelerates mammary tumorigenesis. Cancer Res 2010;70:7684-9.

258. Kopp JL, von Figura G, Mayes E, Liu FF, Dubois CL, Morris JP 4 th, et al. Identification of Sox9-dependent acinar-to-ductal reprogramming as the principal mechanism for initiation of pancreatic ductal adenocarcinoma. Cancer Cell 2012;22:73750.

259. Draznin B. Mitogenic action of insulin: friend, foe or 'frenemy’? Diabetologia 2010;53:229-33.

260. Draznin B. Mechanism of the mitogenic influence of hyperinsulinemia. Diabetol Metab Syndr 2011;3:10.

261. Draznin B, Miles P, Kruszynska Y, Olefsky J, Friedman J, Golovchenko I, et al. Effects of insulin on prenylation as a mechanism of potentially detrimental influence of hyperinsulinemia. Endocrinology 2000;141:1310-6.

262. Goalstone ML, Wall K, Leitner JW, Kurowski T, Ruderman N, 
Pan SJ, et al. Increased amounts of farnesylated p21Ras in tissues of hyperinsulinaemic animals. Diabetologia 1999;42: 310-6.

263. Stephens E, Thureen PJ, Goalstone ML, Anderson MS, Leitner JW, Hay WW Jr, et al. Fetal hyperinsulinemia increases farnesylation of p21 Ras in fetal tissues. Am J Physiol Endocrinol Metab 2001;281:E217-23.

264. Jemal A, Siegel R, Ward E, Murray T, Xu J, Smigal C, et al. Cancer statistics, 2006. CA Cancer J Clin 2006;56:106-30.

265. Hjartaker A, Langseth H, Weiderpass E. Obesity and diabetes epidemics: cancer repercussions. Adv Exp Med Biol 2008;630: 72-93.

266. Koorstra JB, Hustinx SR, Offerhaus GJ, Maitra A. Pancreatic carcinogenesis. Pancreatology 2008;8:110-25.

267. Permuth-Wey J, Egan KM. Family history is a significant risk factor for pancreatic cancer: results from a systematic review and meta-analysis. Fam Cancer 2009;8:109-17.

268. Hart AR, Kennedy H, Harvey I. Pancreatic cancer: a review of the evidence on causation. Clin Gastroenterol Hepatol 2008;6: 275-82.

269. Renehan AG, Tyson M, Egger M, Heller RF, Zwahlen M. Body-mass index and incidence of cancer: a systematic review and meta-analysis of prospective observational studies. Lancet 2008;371:569-78.

270. Lowenfels AB, Maisonneuve P. Risk factors for pancreatic cancer. J Cell Biochem 2005;95:649-56.

271. Li D, Xie K, Wolff R, Abbruzzese JL. Pancreatic cancer. Lancet 2004;363:1049-57.

272. Lauby-Secretan B, Scoccianti C, Loomis D, Grosse Y, Bianchini F, Straif K, et al. Body fatness and cancer: viewpoint of the IARC Working Group. N Engl J Med 2016;375:794-8.

273. Hassan MM, Bondy ML, Wolff RA, Abbruzzese JL, Vauthey JN, Pisters PW, et al. Risk factors for pancreatic cancer: casecontrol study. Am J Gastroenterol 2007;102:2696-707.

274. Perrin MC, Terry MB, Kleinhaus K, Deutsch L, Yanetz R, Tiram $\mathrm{E}$, et al. Gestational diabetes as a risk factor for pancreatic cancer: a prospective cohort study. BMC Med 2007;5:25.

275. Kuriki K, Hirose K, Tajima K. Diabetes and cancer risk for all and specific sites among Japanese men and women. Eur J Cancer Prev 2007;16:83-9.

276. Lu XH, Wang L, Li H, Qian JM, Deng RX, Zhou L. Establishment of risk model for pancreatic cancer in Chinese Han population. World J Gastroenterol 2006;12:2229-34.

277. Bonelli L, Aste H, Bovo P, Cavallini G, Felder M, Gusmaroli R, et al. Exocrine pancreatic cancer, cigarette smoking, and dia- betes mellitus: a case-control study in northern Italy. Pancreas 2003;27:143-9.

278. Huxley R, Ansary-Moghaddam A, Berrington de Gonzalez A, Barzi F, Woodward M. Type-II diabetes and pancreatic cancer: a meta-analysis of 36 studies. Br J Cancer 2005;92:207683.

279. Jian Z, Cheng T, Zhang Z, Raulefs S, Shi K, Steiger K, et al. Glycemic variability promotes both local invasion and metastatic colonization by pancreatic ductal adenocarcinoma. Cell Mol Gastroenterol Hepatol 2018;6:429-49.

280. Sharma A, Smyrk TC, Levy MJ, Topazian MA, Chari ST. Fasting blood glucose levels provide estimate of duration and progression of pancreatic cancer before diagnosis. Gastroenterology 2018;155:490-500.

281. Singhi AD, Koay EJ, Chari ST, Maitra A. Early detection of pancreatic cancer: opportunities and challenges. Gastroenterology 2019;156:2024-40.

282. Sharma A, Chari ST. Pancreatic cancer and diabetes mellitus. Curr Treat Options Gastroenterol 2018;16:466-78.

283. Abbruzzese JL, Andersen DK, Borrebaeck CA, Chari ST, Costello E, Cruz-Monserrate Z, et al. The interface of pancreatic cancer with diabetes, obesity, and inflammation: research gaps and opportunities: summary of a National Institute of Diabetes and Digestive and Kidney Diseases Workshop. Pancreas 2018;47:516-25.

284. Carreras-Torres R, Johansson M, Gaborieau V, Haycock PC, Wade $\mathrm{KH}$, Relton $\mathrm{CL}$, et al. The role of obesity, type 2 diabetes, and metabolic factors in pancreatic cancer: a Mendelian randomization study. J Natl Cancer Inst 2017;109:djx012.

285. Bernal-Mizrachi E, Fatrai S, Johnson JD, Ohsugi M, Otani K, Han Z, et al. Defective insulin secretion and increased susceptibility to experimental diabetes are induced by reduced Akt activity in pancreatic islet beta cells. J Clin Invest 2004;114: 928-36.

286. De Boer R, Beith J, Chirgwin J, Chua S, Colosimo M, Francis P, et al. Systemic treatment of HER2+ metastatic breast cancer: clinical conundrums and future perspectives. Asia Pac J Clin Oncol 2014;10 Suppl S4:15-25.

287. Henderson JR, Daniel PM, Fraser PA. The pancreas as a single organ: the influence of the endocrine upon the exocrine part of the gland. Gut 1981;22:158-67.

288. Maclean N, Ogilvie RF. Quantitative estimation of the pancreatic islet tissue in diabetic subjects. Diabetes 1955;4:367-76.

289. Wright JJ, Saunders DC, Dai C, Poffenberger G, Cairns B, Serreze DV, et al. Decreased pancreatic acinar cell number in 
type 1 diabetes. Diabetologia 2020;63:1418-23.

290. Dombrowski F, Mathieu C, Evert M. Hepatocellular neoplasms induced by low-number pancreatic islet transplants in autoimmune diabetic BB/Pfd rats. Cancer Res 2006;66:183343.

291. Evert M, Sun J, Pichler S, Slavova N, Schneider-Stock R, Dombrowski F. Insulin receptor, insulin receptor substrate-1, Raf1 , and Mek-1 during hormonal hepatocarcinogenesis by intrahepatic pancreatic islet transplantation in diabetic rats. Cancer Res 2004;64:8093-100.

292. Mohammed A, Janakiram NB, Brewer M, Ritchie RL, Marya A, Lightfoot $\mathrm{S}$, et al. Antidiabetic drug metformin prevents progression of pancreatic cancer by targeting in part cancer stem cells and mTOR signaling. Transl Oncol 2013;6:649-59.

293. Li D, Yeung SC, Hassan MM, Konopleva M, Abbruzzese JL. Antidiabetic therapies affect risk of pancreatic cancer. Gastroenterology 2009;137:482-8.

294. Kisfalvi K, Eibl G, Sinnett-Smith J, Rozengurt E. Metformin disrupts crosstalk between $\mathrm{G}$ protein-coupled receptor and insulin receptor signaling systems and inhibits pancreatic cancer growth. Cancer Res 2009;69:6539-45.

295. Vigneri P, Frasca F, Sciacca L, Pandini G, Vigneri R. Diabetes and cancer. Endocr Relat Cancer 2009;16:1103-23.

296. Schneider MB, Matsuzaki H, Haorah J, Ulrich A, Standop J, Ding XZ, et al. Prevention of pancreatic cancer induction in hamsters by metformin. Gastroenterology 2001;120:1263-70.

297. Bodmer M, Becker C, Meier C, Jick SS, Meier CR. Use of antidiabetic agents and the risk of pancreatic cancer: a case-control analysis. Am J Gastroenterol 2012;107:620-6.

298. Stevens RJ, Ali R, Bankhead CR, Bethel MA, Cairns BJ, Camisasca RP, et al. Cancer outcomes and all-cause mortality in adults allocated to metformin: systematic review and collaborative meta-analysis of randomized clinical trials. Diabetologia 2012;55:2593-603.

299. Li X, Li T, Liu Z, Gou S, Wang C. The effect of metformin on survival of patients with pancreatic cancer: a meta-analysis. Sci Rep 2017;7:5825.

300. Aljada A, Mousa SA. Metformin and neoplasia: implications and indications. Pharmacol Ther 2012;133:108-15.

301. Jalving M, Gietema JA, Lefrandt JD, de Jong S, Reyners AK, Gans RO, et al. Metformin: taking away the candy for cancer? Eur J Cancer 2010;46:2369-80.

302. Martin-Castillo B, Vazquez-Martin A, Oliveras-Ferraros C, Menendez JA. Metformin and cancer: doses, mechanisms and the dandelion and hermetic phenomena. Cell Cycle 2010;
9:1057-64.

303. Sinnett-Smith J, Kisfalvi K, Kui R, Rozengurt E. Metformin inhibition of mTORC1 activation, DNA synthesis and proliferation in pancreatic cancer cells: dependence on glucose concentration and role of AMPK. Biochem Biophys Res Commun 2013;430:352-7.

304. Dawson DW, Hertzer K, Moro A, Donald G, Chang HH, Go VL, et al. High-fat, high-calorie diet promotes early pancreatic neoplasia in the conditional KrasG12D mouse model. Cancer Prev Res (Phila) 2013;6:1064-73.

305. Andersen DK. Diabetes and cancer: placing the association in perspective. Curr Opin Endocrinol Diabetes Obes 2013;20: 81-6.

306. Strickler HD, Wylie-Rosett J, Rohan T, Hoover DR, Smoller S, Burk RD, et al. The relation of type 2 diabetes and cancer. Diabetes Technol Ther 2001;3:263-74.

307. McCarty MF. Insulin secretion as a determinant of pancreatic cancer risk. Med Hypotheses 2001;57:146-50.

308. DeMeo MT. Pancreatic cancer and sugar diabetes. Nutr Rev 2001;59:112-5.

309. Waks AG, Winer EP. Breast cancer treatment: a review. JAMA 2019;321:288-300.

310. Blair CK, Wiggins CL, Nibbe AM, Storlie CB, Prossnitz ER, Royce $\mathrm{M}$, et al. Obesity and survival among a cohort of breast cancer patients is partially mediated by tumor characteristics. NPJ Breast Cancer 2019;5:33.

311. Michels KB, Solomon CG, Hu FB, Rosner BA, Hankinson SE, Colditz GA, et al. Type 2 diabetes and subsequent incidence of breast cancer in the Nurses' Health Study. Diabetes Care 2003;26:1752-8.

312. Boyle P, Boniol M, Koechlin A, Robertson C, Valentini F, Coppens $\mathrm{K}$, et al. Diabetes and breast cancer risk: a metaanalysis. Br J Cancer 2012;107:1608-17.

313. Coughlin SS, Calle EE, Teras LR, Petrelli J, Thun MJ. Diabetes mellitus as a predictor of cancer mortality in a large cohort of US adults. Am J Epidemiol 2004;159:1160-7.

314. Kaplan MA, Pekkolay Z, Kucukoner M, Inal A, Urakci Z, Ertugrul $\mathrm{H}$, et al. Type 2 diabetes mellitus and prognosis in early stage breast cancer women. Med Oncol 2012;29:1576-80.

315. Luo J, Virnig B, Hendryx M, Wen S, Chelebowski R, Chen C, et al. Diabetes, diabetes treatment and breast cancer prognosis. Breast Cancer Res Treat 2014;148:153-62.

316. Neuhouser ML, Aragaki AK, Prentice RL, Manson JE, Chlebowski R, Carty CL, et al. Overweight, obesity, and postmenopausal invasive breast cancer risk: a secondary analysis 
of the Women's Health Initiative randomized clinical trials. JAMA Oncol 2015;1:611-21.

317. Matthews SB, Thompson HJ. The obesity-breast cancer conundrum: an analysis of the issues. Int J Mol Sci 2016;17:989.

318. Larsson SC, Mantzoros CS, Wolk A. Diabetes mellitus and risk of breast cancer: a meta-analysis. Int J Cancer 2007;121: 856-62.

319. Renehan AG, Yeh HC, Johnson JA, Wild SH, Gale EA, Moller $\mathrm{H}$, et al. Diabetes and cancer (2): evaluating the impact of diabetes on mortality in patients with cancer. Diabetologia 2012; 55:1619-32.

320. Park YM, White AJ, Nichols HB, O’Brien KM, Weinberg CR, Sandler DP. The association between metabolic health, obesity phenotype and the risk of breast cancer. Int J Cancer 2017; 140:2657-66.

321. Kabat GC, Kim MY, Lee JS, Ho GY, Going SB, Beebe-Dimmer $\mathrm{J}$, et al. Metabolic obesity phenotypes and risk of breast cancer in postmenopausal women. Cancer Epidemiol Biomarkers Prev 2017;26:1730-5.

322. Cao Z, Zheng X, Yang H, Li S, Xu F, Yang X, et al. Association of obesity status and metabolic syndrome with site-specific cancers: a population-based cohort study. Br J Cancer 2020; 123:1336-44.

323. Keum N, Greenwood DC, Lee DH, Kim R, Aune D, Ju W, et al. Adult weight gain and adiposity-related cancers: a dose-response meta-analysis of prospective observational studies. J Natl Cancer Inst 2015;107:djv088.

324. Yuan S, Kar S, Carter P, Vithayathil M, Mason AM, Burgess S, et al. Is type 2 diabetes causally associated with cancer risk?: evidence from a two-sample mendelian randomization study. Diabetes 2020;69:1588-96.

325. Yeh HC, Platz EA, Wang NY, Visvanathan K, Helzlsouer KJ, Brancati FL. A prospective study of the associations between treated diabetes and cancer outcomes. Diabetes Care 2012;35: 113-8.

326. Simon MS, Beebe-Dimmer JL, Hastert TA, Manson JE, Cespedes Feliciano EM, Neuhouser ML, et al. Cardiometabolic risk factors and survival after breast cancer in the Women's Health Initiative. Cancer 2018;124:1798-807.

327. Chen WW, Shao YY, Shau WY, Lin ZZ, Lu YS, Chen HM, et al. The impact of diabetes mellitus on prognosis of early breast cancer in Asia. Oncologist 2012;17:485-91.

328. Friberg E, Orsini N, Mantzoros CS, Wolk A. Diabetes mellitus and risk of endometrial cancer: a meta-analysis. Diabetologia 2007;50:1365-74.
329. Zhang ZH, Su PY, Hao JH, Sun YH. The role of preexisting diabetes mellitus on incidence and mortality of endometrial cancer: a meta-analysis of prospective cohort studies. Int J Gynecol Cancer 2013;23:294-303.

330. Luo J, Beresford S, Chen C, Chlebowski R, Garcia L, Kuller L, et al. Association between diabetes, diabetes treatment and risk of developing endometrial cancer. Br J Cancer 2014;111: 1432-9.

331. Endogenous Hormones and Breast Cancer Collaborative Group, Key TJ, Appleby PN, Reeves GK, Travis RC, Alberg AJ, et al. Sex hormones and risk of breast cancer in premenopausal women: a collaborative reanalysis of individual participant data from seven prospective studies. Lancet Oncol 2013; 14:1009-19.

332. Onstad MA, Schmandt RE, Lu KH. Addressing the role of obesity in endometrial cancer risk, prevention, and treatment. J Clin Oncol 2016;34:4225-30.

333. Reeves KW, Carter GC, Rodabough RJ, Lane D, McNeeley SG, Stefanick ML, et al. Obesity in relation to endometrial cancer risk and disease characteristics in the Women's Health Initiative. Gynecol Oncol 2011;121:376-82.

334. Terry P, Baron JA, Weiderpass E, Yuen J, Lichtenstein P, Nyren O. Lifestyle and endometrial cancer risk: a cohort study from the Swedish Twin Registry. Int J Cancer 1999;82:38-42.

335. Anderson KE, Anderson E, Mink PJ, Hong CP, Kushi LH, Sellers TA, et al. Diabetes and endometrial cancer in the Iowa women's health study. Cancer Epidemiol Biomarkers Prev 2001;10:611-6.

336. La Vecchia C, Negri E, Franceschi S, D’Avanzo B, Boyle P. A case-control study of diabetes mellitus and cancer risk. Br J Cancer 1994;70:950-3.

337. Gunter MJ, Hoover DR, Yu H, Wassertheil-Smoller S, Rohan TE, Manson JE, et al. Insulin, insulin-like growth factor-I, and risk of breast cancer in postmenopausal women. J Natl Cancer Inst 2009;101:48-60.

338. Bruning PF, Bonfrer JM, van Noord PA, Hart AA, de JongBakker M, Nooijen WJ. Insulin resistance and breast-cancer risk. Int J Cancer 1992;52:511-6.

339. Conover CA, Lee PD, Kanaley JA, Clarkson JT, Jensen MD. Insulin regulation of insulin-like growth factor binding protein-1 in obese and nonobese humans. J Clin Endocrinol Metab 1992;74:1355-60.

340. van der Burg B, Rutteman GR, Blankenstein MA, de Laat SW, van Zoelen EJ. Mitogenic stimulation of human breast cancer cells in a growth factor-defined medium: synergistic action of 
insulin and estrogen. J Cell Physiol 1988;134:101-8.

341. Beckwith H, Yee D. Insulin-like growth factors, insulin, and growth hormone signaling in breast cancer: implications for targeted therapy. Endocr Pract 2014;20:1214-21.

342. Katzenellenbogen BS, Norman MJ. Multihormonal regulation of the progesterone receptor in MCF-7 human breast cancer cells: interrelationships among insulin/insulin-like growth factor-I, serum, and estrogen. Endocrinology 1990;126:891-8.

343. Johnson JA, Bowker SL. Intensive glycaemic control and cancer risk in type 2 diabetes: a meta-analysis of major trials. Diabetologia 2011;54:25-31.

344. Yang XL, Ma RC, Chan JC. Meta-analysis of trial data may support a causal role of hyperglycaemia in cancer. Diabetologia 2011;54:709-10.

345. Chlebowski RT, McTiernan A, Wactawski-Wende J, Manson JE, Aragaki AK, Rohan T, et al. Diabetes, metformin, and breast cancer in postmenopausal women. J Clin Oncol 2012; 30:2844-52.

346. Pimentel I, Lohmann AE, Ennis M, Dowling RJ, Cescon D, Elser $\mathrm{C}$, et al. A phase II randomized clinical trial of the effect of metformin versus placebo on progression-free survival in women with metastatic breast cancer receiving standard chemotherapy. Breast 2019;48:17-23.

347. Pimentel I, Chen BE, Lohmann AE, Ennis M, Ligibel J, Shepherd L, et al. The effect of metformin vs placebo on sex hormones in CCTG MA.32. J Natl Cancer Inst 2021;113:192-8.

348. Madariaga A, Goodwin PJ, Oza AM. Metformin in gynecologic cancers: opening a new window for prevention and treatment? Clin Cancer Res 2020;26:523-5.

349. Fernandez AM, Kim JK, Yakar S, Dupont J, Hernandez-Sanchez C, Castle AL, et al. Functional inactivation of the IGF-I and insulin receptors in skeletal muscle causes type 2 diabetes. Genes Dev 2001;15:1926-34.

350. Shlomai G, Zelenko Z, Antoniou IM, Stasinopoulos M, Tobin-Hess A, Vitek MP, et al. OP449 inhibits breast cancer growth without adverse metabolic effects. Endocr Relat Cancer 2017;24:519-29.

351. Gallagher EJ, Alikhani N, Tobin-Hess A, Blank J, Buffin NJ, Zelenko Z, et al. Insulin receptor phosphorylation by endogenous insulin or the insulin analog AspB10 promotes mammary tumor growth independent of the IGF-I receptor. Diabetes 2013;62:3553-60.

352. Pan F, Hong LQ. Insulin promotes proliferation and migration of breast cancer cells through the extracellular regulated kinase pathway. Asian Pac J Cancer Prev 2014;15:6349-52.
353. Corpet DE, Jacquinet C, Peiffer G, Tache S. Insulin injections promote the growth of aberrant crypt foci in the colon of rats. Nutr Cancer 1997;27:316-20.

354. Venkateswaran V, Haddad AQ, Fleshner NE, Fan R, Sugar LM, Nam R, et al. Association of diet-induced hyperinsulinemia with accelerated growth of prostate cancer ( $\mathrm{LNCaP}$ ) xenografts. J Natl Cancer Inst 2007;99:1793-800.

355. Ding XZ, Fehsenfeld DM, Murphy LO, Permert J, Adrian TE. Physiological concentrations of insulin augment pancreatic cancer cell proliferation and glucose utilization by activating MAP kinase, PI3 kinase and enhancing GLUT-1 expression. Pancreas 2000;21:310-20.

356. Zhang H, Fagan DH, Zeng X, Freeman KT, Sachdev D, Yee D. Inhibition of cancer cell proliferation and metastasis by insulin receptor downregulation. Oncogene 2010;29:2517-27.

357. Santoro MA, Blue RE, Andres SF, Mah AT, Van Landeghem L, Lund PK. Obesity and intestinal epithelial deletion of the insulin receptor, but not the IGF 1 receptor, affect radiation-induced apoptosis in colon. Am J Physiol Gastrointest Liver Physiol 2015;309:G578-89.

358. Ulanet DB, Ludwig DL, Kahn CR, Hanahan D. Insulin receptor functionally enhances multistage tumor progression and conveys intrinsic resistance to IGF-1R targeted therapy. Proc Natl Acad Sci U S A 2010;107:10791-8.

359. Clemmons DR, Underwood LE. Nutritional regulation of IGF-I and IGF binding proteins. Annu Rev Nutr 1991;11:393412.

360. Straus DS. Nutritional regulation of hormones and growth factors that control mammalian growth. FASEB J 1994;8:6-12.

361. Calle EE, Kaaks R. Overweight, obesity and cancer: epidemiological evidence and proposed mechanisms. Nat Rev Cancer 2004;4:579-91.

362. Denduluri SK, Idowu O, Wang Z, Liao Z, Yan Z, Mohammed $\mathrm{MK}$, et al. Insulin-like growth factor (IGF) signaling in tumorigenesis and the development of cancer drug resistance. Genes Dis 2015;2:13-25.

363. Plymate SR, Matej LA, Jones RE, Friedl KE. Inhibition of sex hormone-binding globulin production in the human hepatoma (Hep G2) cell line by insulin and prolactin. J Clin Endocrinol Metab 1988;67:460-4.

364. Coussens LM, Werb Z. Inflammation and cancer. Nature 2002;420:860-7.

365. Singh N, Baby D, Rajguru JP, Patil PB, Thakkannavar SS, Pujari VB. Inflammation and cancer. Ann Afr Med 2019;18:1216. 
366. Hopkins BD, Pauli C, Du X, Wang DG, Li X, Wu D, et al. Suppression of insulin feedback enhances the efficacy of PI3K inhibitors. Nature 2018;560:499-503.

367. Kasznicki J, Sliwinska A, Drzewoski J. Metformin in cancer prevention and therapy. Ann Transl Med 2014;2:57.

368. Saraei P, Asadi I, Kakar MA, Moradi-Kor N. The beneficial ef- fects of metformin on cancer prevention and therapy: a comprehensive review of recent advances. Cancer Manag Res 2019; 11:3295-313.

369. Sanaki Y, Nagata R, Kizawa D, Leopold P, Igaki T. Hyperinsulinemia drives epithelial tumorigenesis by abrogating cell competition. Dev Cell 2020;53:379-89. 